\title{
Modernity, Frontiers and Revolutions
}

\section{phi}

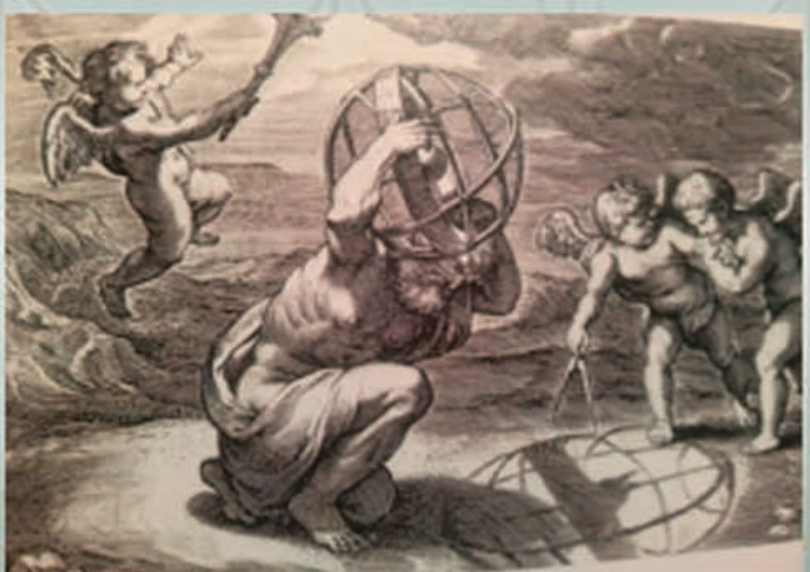

Chief-Editors:

Maria do Rosário Monteiro Mário S. Ming Kong

Co-Editor:

Maria Jocäo Pereira Neto 
MODERNITY, FRONTIERS AND REVOLUTIONS 


\section{PHI (Book Series)}

ISSN Print: 2161-3907

ISSN Online: 2639-0205

\section{Series Editors}

\section{Mário S. Ming Kong}

CIAUD - FAUL, Lisbon School of Architecture, Lisbon University, Lisbon, Portugal

\section{Maria do Rosário Monteiro}

Faculdade de Ciências Sociais e Humanas, Universidade NOVA de Lisboa 


\section{Modernity, Frontiers and Revolutions}

Editors:

Maria do Rosário Monteiro \& Mário S. Ming Kong CHAM, FCSH, Universidade NOVA de Lisboa, Lisbon, Portugal CIAUD-FA ULisboa, Lisbon, Portugal

Co-editor:

Maria João Pereira Neto CIAUD-FA ULisboa, Lisbon, Portugal

CHAM, FCSH, Universidade NOVA de Lisboa, Lisbon, Portugal 
CRC Press/Balkema is an imprint of the Taylor \& Francis Group, an informa business

(C) 2019 Taylor \& Francis Group, London, UK

Typeset by V Publishing Solutions Pvt Ltd., Chennai, India

All rights reserved. No part of this publication or the information contained herein may be reproduced, stored in a retrieval system, or transmitted in any form or by any means, electronic, mechanical, by photocopying, recording or otherwise, without written prior permission from the publisher.

Although all care is taken to ensure integrity and the quality of this publication and the information herein, no responsibility is assumed by the publishers nor the author for any damage to the property or persons as a result of operation or use of this publication and/or the information contained herein.

Published by: CRC Press/Balkema

Schipholweg 107C, 2316 XC Leiden, The Netherlands

e-mail: Pub.NL@taylorandfrancis.com

www.crcpress.com - www.taylorandfrancis.com

ISBN: 978-0-367-02397-3 (Hbk)

ISBN: 978-0-429-39983-1 (eBook) 


\section{Table of contents}

Editorial foreword $\quad$ ix

Preface $\quad$ xi

M.S.M. Kong

Committees $\quad$ xiii

Sponsors $\quad$ xxix

Introduction $\quad$ xxxi

M.S.M. Kong

Part I: Modernity: Frontiers and revolutions

Know how and cultural context: From ideas to facts and from facts to ideas 3

M. Silva

A silent revolution $\quad 11$

J. Seixas

A paradigm for the $21^{\text {st }}$ century considering fuzzy logic

G. Braviano

Modernity, revolutions and frontiers in Philip Pullman's His Dark Materials or a contribution to the fourth culture

M. do Rosário Monteiro

\section{Part II: Architecture/urbanism/design}

The invention of the architect: The reiteration of the scale model as a representational system under the definition of a new paradigm for the profession

J.M. Couto Duarte

Architecture and modern science: The mathematics of the circle - arithmetic and geometry as figure and symbol in the Renaissance and Baroque

C.G. Gonçalves

Revolutionised through glass: Russian modernism in the age of the Crystal Palace

I. Seits

$19^{\text {th }}$ century industrial architecture related to the "olive grove revolution" in the province

of Jaén, Spain

S.P. Alarcón

The "Joy at work" as a revolution: Evolution of the industrial space, from the place of production to one of re-creation

R. Maddaluno

Vienna 1900: Stage of modernities

J. Nunes

The machine of living in Brazil: An Oscar Niemeyer experience

E. Kuchpil \& A. Pimentel dos Santos

The Ural Architectural School: Integration into the international higher education space:

Utopia or reality?

I. V. Tarasova 
Architecture of representation $\mathrm{X}$ architecture of living

G. M. de Carvalho

Cultural anthropophagy and regionalism in the architectures of Brazil and Portugal

in the $20^{\text {th }}$ century

U.M. de Andrade

Expressiveness and figuration in the construction of social architecture

D. Chizzoniti \& M. Moscatelli

Lean alternative: The plastic use of concrete in the architecture of Paolo Soleri

in the United States of America

P. Viscomi

Like a machine in motion: The modernity of the Cagliari Opera House and the Osaka

Expo Pavilion by Maurizio Sacripanti

S. Centineo

The influence of the proposals of the sixties: An 'open' context of the contemporary city in a new hypermodern era

A.M. Feliciano

Modernity and preservation in Casa Forte: The dialogue between the frontier of the new and the protection of the ancient

T. Fonseca, A. Fonseca \& F. Moreira da Silva

Out of the BOX - into the BIM: The limits and paradoxes of creative thinking and the new frontiers for architecture teaching

F. Oliveira

Castle cities and their contribution to modern Japan

F. Carmo

A perspective on the Portuguese identity: The idea of modernity in A Exposição do Mundo Português and Expo'98

A. Neiva \& J. Cabral Dias

Beyond self-hating urbanism; Identifying a common pathology

J. Silva Jordão

The urban project as a holistic approach to the recovery of degraded areas of public housing

C. Montalbano

An interscalar approach to the recovery of degraded neighbourhoods of public housing

C. Chiarantoni

Dwelling on the border; A strategy for refugees in the town of Calais

M. Louro \& B. Ribeiro

Finitio: Afore and beyond limit in the binomial We and Others

J.L. Morgado

From palimpsest to an intentional identity re-inscription: The value and ways of preserving an 'identity essence' in the urban and architectural rehabilitation of our contemporaneity

A. Santos Leite

A quiet revolution: Electric mobility and the new city soundscape

P.C. Monteiro

The project as an instrument of social participation - inclusive and reverential ecology project

F. Moreira da Silva

Interactive printed book: A design experience

M. Neves \& I. Caixeiro

Production of didactic material for visually impaired children in science teaching

B. de Cássia Xavier Cassins Aguiar, G. de França Aguiar, A.F. Andrade \& Q.S. Coden 
Production of didactic material for the visually impaired in mathematics teaching

B. de Cássia Xavier Cassins Aguiar, G. de França Aguiar, A.F. Andrade \& Q.S. Coden

Developing a trumpet configuration applying a methodology from design-by-drawing and craft evolution

E. Aparo, F. Moreira da Silva \& L. Soares

Standardisation of the female body and the plus-size market

C. de Holanda Sousa Matos Sousa, M.J. Pereira Neto \& H.P. Lopes

\section{Part III: Arts}

The self-reflection of the artist's hands

D. Swartz

The modern paradigm of art and its frontiers

G. Horváth

Imaginary construction in visual art: The case of Piranesi and Matta-Clark

S. Paiva de Sousa \& M. Baptista-Bastos

Modernity and frontiers: Art travel in the colonial context

M.J. Castro

False sailing maps

A.L.M.M. Rodrigues

Le Portugais by Georges Braque: A frontier and evocative boundary-place

Free-hand drawing versus new technologies in project creative process

A. Moreira da Silva

Digital technologies, a modern medium: Pushing frontiers through a creative artistic approach

A. Canau

Graphite and pixel: Related knowledge of modernity

A.R. Ortega \& S. Weihermann

\section{Part IV: Humanities}

Revolutions in film in the postmodern narrative: A matter of illusion and memory

I. Borbely

Ideals, reality and frontiers of human existence in fiction films: Their expression, representation, living, telling and space

C.M. Figueiredo

Praising silence in the modern literary artwork

F. Ribeiro

April in fantasy: Polyphonic memories of the revolution

M. Rendeiro

Modernity, gender and cultural representations in the work of Mozambican writer Suleiman Cassamo: Redefining the revolution and its legacy

A.M. Martinho Gale

Breaking boundaries, challenging modernity, building revolutions: Rap in Portugal and its new generation of female voices

F. Lupati

The early sixties in the $20^{\text {th }}$ century and their artistic expressions: The third and last Portuguese Modernism

M. Baptista-Bastos \& S. Paiva de Sousa 
A hero with many faces; The frontiers of authorial identity in translated texts

L. Sampaio da Silva

Crossing borders and dreaming the revolution in Nuno Bragança's A Noite e o Riso

L.S. Loureiro

Alexandria, the building of an imaginary city; Frontiers and silent, inner revolutions

M. Avelar

New winds, distinct times of the Church: The activity of Bishop Sardinha and

the Provincial Nóbrega in Brazil (16 $6^{\text {th }}$ century)

M. Boscariol

Ways of negotiating, social frontiers and modernity

M.L.G. da Cruz

Revolts and revolutions under slavery

Tradition and modernity in the memory of an empire: The writing of A. Lopes Mendes

A.P. Avelar

Demystifying oriental alterities: Pedro Teixeira and the early modern scientificity regarding the past

M. de Fátima Rosa \& I. Almeida

Exploring Africa in the Nordic Press. David Livingstone, Henry Stanley and the popular fascination with exploration and adventure in Africa in the late $19^{\text {th }}$ century

K.S. Groop

The contribution of Lusophone publishing in the autonomy of the periphery: Exile, diaspora, anti-colonialism and national literature in Africa

D. Melo

Alfredo Bensaúde: A "revolutionary" in the training of engineers

A. Cardoso de Matos \& M. da Luz Sampaio

Part V: Social sciences

Universal Exhibition Paris 1900: Celebration of modernity, women and fashion

M.J. Pereira Neto

A revolutionary humanitarian: The moral socialism of Richard Congreve

M. Wilson

Mediator of modernity: Anders Svedberg as a link between the elite and the peasantry and between tradition and modernity

J. Dahlbacka

"Das Wunder von Leipzig"; The Paulinum in Leipzig and palimpsestic memories of oppression and revolution

K.S. Groop

Transculturation and translanguaging as representation of second modernity:

Polish migrants in the East Midlands, UK

R. Seredynska-Abou Eid

Destination development along the Austrian-Hungarian border

R. Bagdi

The role of flight specification in travel decision making

A. Mondok, M. Kóródi, A. Szabó \& R. Bakos

What revolution could be in the times of biocapitalism?

S. Wróbel

Author index 


\title{
Editorial foreword
}

It is our pleasure to present the fourth volume of Proportion, Harmony, and Identities (PHI). It is the theoretical basis for the fourth INTERNATIONAL MULTIDISCIPLINARY CONGRESS PHI 2018, held at the University of the Azores, Ponta Delgada, S. Miguel, Portugal, on October $3^{\text {rd }}$ to $6^{\text {th }}, 2018$.

The Congress was designed as a platform for researchers, academics and students to present, share and exchange ideas, visions of the past and the future and research results applicable to Architecture, Urban Planning, Design, Arts, Humanities, Engineering, Social and Natural Sciences and Technology, among others, on the importance of harmony and proportion as subjects that define, differentiate and unite identities. This year's book and Congress are dedicated to the theme Modernity, Frontiers and Revolutions.

We received ninety-four papers from nine countries and after an intense process of scrutiny through the double-blind peer review method, and a rigorous linguistic review, sixty-eight papers were selected for presentation and publication as chapters of this volume. In this sense, this book represents the combined effort of scholars from Brazil, Canada, Finland, Hungary, Israel, Italy, Romania, Poland, Portugal, Russia, Spain, Sweden, Ukraine, the United Kingdom and the United States of America.

We decided to organise the publication in five major sections, each divided into chapters. The first, bearing the same title as the book itself, is formed by chapters that serve, in our opinion, as relevant introductions to the diversity and complexity of themes involving Modernity, Frontiers and Revolutions in a multidisciplinary perspective. In the first part, that includes the chapters provided by some of our invited Keynotes, the reader will find texts on technology and culture, on quantum physics, on logic and expression of all this in selected literary texts.

The second section approaches Modernity, Frontiers and Revolutions from the point of view of Architecture, Urban Planning and Design, or to formulate it differently, this section deals with the city, and its evolution based on the concept of Modernity: Frontiers and Revolutions.

The third section assembles texts dealing with Modernity, Frontiers and Revolutions in Arts, approaching different perspectives on their importance and influence on the development of society, knowledge, time and space.

The fourth section assembles chapters under the vast umbrella of Humanities: narratology, literature, cultural heritage, philosophy and history.

The fifth and final section is dedicated to Social Sciences. All sections are organised.

Apart from our intervention in the organisation of the volume, all individual chapters are the sole responsibility of their respective authors.

We thank all members of the scientific committee, partner universities, and their research centres, organising committee members, and especially all the participants for making this book and the Congress possible.

\author{
Maria do Rosário Monteiro \\ (Professor/Researcher CHAM, FCSH, Universidade NOVA de Lisboa) \\ Chief-Editor, PHI 2018 Congress Organising Chairperson
}

\author{
Mário S. Ming Kong \\ (Professor/Researcher, CIAUD- FA ULisboal CHAM, FCSH, Universidade NOVA de Lisboa) \\ Chief-Editor, PHI 2018 Congress Organising Chairperson \\ Maria João Pereira Neto \\ (Professor/Researcher, CIAUD- FA ULisboal CHAM, FCSH, Universidade NOVA de Lisboa) \\ Co-Editor, PHI 2018 Congress Co-Organising Chairperson
}


$\because$ Taylor \& Francis

Taylor \& Francis Group

http://taylorandfrancis.com 


\section{Preface}

We are pleased to welcome you to the book Proportion, Harmony and Identities (PHI) Modernity, Frontiers and Revolutions, the result of the $4^{\text {th }}$ INTERNATIONAL MULTIDISCIPLINARY CONGRESS PHI held at the University of the Azores, Ponta Delgada, S. Miguel, and Azores, Portugal from the $3^{\text {rd }}$ to the $6^{\text {th }}$ of October 2018.

The books and congresses Proportion, Harmony and Identities (PHI) are annual international events for the presentation, interaction and dissemination of multidisciplinary researches related to the topic of Harmony, Proportion and Identity relevant to Architecture, Arts and Humanities, Design, Engineering and Social and Natural Sciences. They aim to foster the awareness and discussion on the importance of multidisciplinarity and its benefits for the community at large.

It is my pleasure to announce the participation of experts from fifteen countries in the three-day event. We have received research papers from distinguished academics and researchers from countries across three continents. Thus, this event revealed itself as a platform for researchers in a vast variety of fields to discuss, share, and exchange experiences. The comprehensive content of the PHI project has attracted immense attention, and the wealth of information spread out over all the texts is, from our point of view, extremely useful for professionals and students working in the related fields.

This publication, containing the full papers, documents and presentations publicly presented during the Congress PHI 2018, is the result of the creative work of their authors and a highly selective peerreview process.

I would like to express my sincere thanks to all those who have contributed to the success of PHI 2018.

The $4^{\text {th }}$ International Multidisciplinary Congress PHI 2018: "Modernity, Frontiers and Revolutions" would not have been possible without the help of a group of people from the Lisbon School of Architecture, University of Lisbon, the Faculty of Human and Social Sciences (FCSH), Universidade NOVA de Lisboa and the University of the Azores. Researchers affiliated with the research centres from these universities - CIAUD and CHAM - selflessly and enthusiastically supported and helped us to overcome the many obstacles that arose during the preparation and organisation of this event.

I want to thank all authors of submitted papers for their participation. All contributed a great deal of effort and creativity to produce this work, and in my capacity as organising chair, I am especially happy that they chose PHI 2018 as the place to present it. Credit also goes to all collaborators, in particular, the Scientific Committee members and reviewers, who donated substantial time from their busy schedules to carefully read and conscientiously evaluate the submissions.

In the name of the Organising Committee, I would like to take this opportunity to extend our sincere gratitude to all subsidiary Organisations, for their support and encouragement and for making the event a success.

Special thanks go to all our speakers, authors, and delegates for making PHI 2018 a fruitful platform for sharing, learning, networking, and inspiration.

We sincerely hope you find this publication enriching and thought-provoking.

Mário S. Ming Kong
PHI 2018 Congress Organizing Chairperson
Professor/Researcher, CIAUD-FAUL, Faculty of Architecture-
University of Lisbon, Lisbon, Portugal
CHAM, FCSH, Universidade NOVA de Lisboa, Lisbon, Portugal
Portugal, October 2018


$\because$ Taylor \& Francis

Taylor \& Francis Group

http://taylorandfrancis.com 


\section{Committees}

\section{ORGANIZING COMMITTEE}

\author{
Chief-Editors
}

Co-Editor
Maria do Rosário Monteiro

CHAM, FCSH, Universidade NOVA de Lisboa, Portugal

Mário S. Ming Kong

CIAUD - FAUL, Lisbon School of Architecture, Lisbon University, Lisbon, Portugal

CHAM, FCSH, Universidade NOVA de Lisboa, Portugal

Maria João Pereira Neto

CIAUD - FAUL, Lisbon School of Architecture, Lisbon University, Lisbon, Portugal

CHAM, FCSH, Universidade NOVA de Lisboa, Portugal

\section{SCIENTIFIC COMMITTEE AND PEER REVIEWERS}

\author{
Aleksander Olszewski \\ Faculty of Art, Kazimierz Pulaski \\ University of Technology and \\ Humanities, Radom, Poland
}

\author{
Ana Cristina Gil \\ Dean FCSH Universidade dos Açores, \\ Senior Researcher Universidade \\ dos Açores, CHAM
}

He studied at the Academy of Fine Arts in Lódź. He is a Professor at the UTH in Radom, a Former Dean of the Faculty of Arts (2009-2016), Head of the Department of Digital Media and Photography. He works in the field of painting and computer graphics. Author of 40 solo exhibitions. Editor of a yearly "Arteria" published by the Art Department of the UTH in Radom. He was awarded the Cross of the Knight to the Order of Poland Restored.

She completed a PhD in Portuguese Culture at the University of the Azores (Portugal) in 2006, with the thesis National Identity in Portuguese Literature. From Fernão Lopes to the end of the Nineteenth Century, published in 2015 by CHAM, of which she is a research member.

Since 1993 she teaches Portuguese Culture, Culture, Identity, and Journalism in the University of the Azores, where she is currently the President of the School of Social Sciences and Humanities. Between 2014 and 2017, she was Director of the Library and Archive of the University of the Azores.

Her research interests are identity issues and their relation to the theory of culture, national culture and nationalisms, with a particular focus on literature. She regularly participates in conferences, in Portugal and abroad, with works about authors and themes connected to Portuguese Culture, such as Alexandre Herculano, Ramalho Ortigão, Antero de Quental, Fialho de Almeida, Vitorino Nemésio, Miguel Torga, Mário de Carvalho, António Lobo Antunes, José Saramago, Gonçalo M. Tavares, Valter Hugo Mãe, Afonso Cruz, Dulce Maria Cardoso and Possidónio Cachapa. She also has some works connected to Communication Studies.

In 2014, she won the Centro de Investigação Joaquim Veríssimo Serrão Prize with the essay «Different perspectives about National Identity: the Portuguese case».

Professor at the Évora University (Department of History) and a member of Research Centre CIDEHUS/UE. She is the responsible at the University of Évora of the Erasmus Mundus Master TPTI-Techniques, patrimoines, territoires de l'industrie. Her research interests are focussed on urban history and the history and heritage of technology, engineering and industry. She has been Visiting Professor at Ėcole des Hautes Études en Science Sociales, Paris (2010-2012). She regularly publishes both in national and international journals. 
Ana Cristina Guerreiro

Senior Researcher, (CIAUD) Centro de Investigação em Arquitetura, Urbanismo e Design - Faculdade de Arquitetura - Universidade de Lisboa, Lisbon, Portugal

Ana Isabel Buescu

Senior Researcher, CHAM, Departamento de História, FCSH, Universidade NOVA de Lisboa, Lisbon, Portugal
Professor at the Lisbon School of Architecture-University of Lisbon, Lisbon, Portugal. She holds a $\mathrm{PhD}$ in Visual Communication by the same Faculty and a Post-degree in History of Art by the FCSH, Nova University of Lisbon. She is graduated in Fine Arts, by the Faculty of Fine Arts in Lisbon. She works and researches in Fine Arts and Theory of Art, including the relation between Arts and Architecture.

Position Associate Professor History Department Faculdade de Ciências Sociais e Humanas Universidade Nova de Lisboa.

Scientific domains \& interests (15th-16th centuries) Portuguese History. Education of princes. Court culture. Royal ceremonies. Royal and aristocratic libraries. Biographical History.

Books (since 2005) Author:

2011 - Na Corte dos Reis de Portugal. Saberes, ritos e memórias. Estudos sobre o Século XVI, Lisboa, Colibri, 266 pp., 1st ed., 2010

2008 - D. João III (1502-1557), 2nd ed. Lisboa, Temas e Debates, 416 p.

2007 - Catarina de Áustria (1507-1578) Infanta de Tordesilhas, Rainha de Portugal, Lisboa, A Esfera dos Livros, $491 \mathrm{p}$.

2005 - D. João III (1502-1557), Lisboa, Círculo de Leitores, 344 p. Indexed Articles (since 2013)

- "Os Santos na Corte de D. João III e de D. Catarina", Lusitania Sacra, 2a série, 28 (Jul.-Dez.), 2013, pp. 49-72. ISSN: 0076-1508 | e ISSN: 21828822 ISBN: 978-972-8361-55-6, http://www.ft.lisboa.ucp.pt/resources/ Documentos/CEHR/Pub/LS/2/Lusitania_Tomo28_indice.pdf

- "Utopia e profetismo no século das Luzes. D. José, Príncipe do Brasil, Imperador do Mundo“, Revista de História da Sociedade e da Cultura (Coimbra), 13, 2013, pp. 283-310. ISSN: 1645-2259

- "Dimensão política e de poder da comida régia e do corpo do rei", Librosdelacorte.es (publicação electrónica www.librosdelacorte.es), 7, año 5, Otoño-invierno 2013 ISSN 1989-6425. http://www.librosdelacorte.es

- "Livros em castelhano na livraria de D. Teodósio I (c.1510-1563), 5o duque de Bragança", Revista de Estudios Humanísticos. Historia (Univ. Léon), 12, 2013, pp. 105-126. ISSN: 1696-0300

- "A livraria de D. Teodósio (1510?-1563), duque de Bragança. A sua dimensão numa perspectiva comparada”, Ler História, vol. 65, 2013, pp. 59-73. ISSN: 0870-6182

Current Research (Projects)

- De Todas as Partes do Mundo, O património do $5^{\circ}$ Duque de Bragança, D. Teodósio I. (PTDC/EAT- HAH/098461/2008), coord. Jessica Hallett/ CHAM (NOVA FCSH-UAc). http://www.cham.fcsh.unl.pt/teodosio/ (researcher)

Visual Artist

Full Professor at University of Lisbon - Faculty of Architecture.

https://analeonorrodrigues.myportfolio.com

pt.linkedin.com/pub/ana-leonor-madeira-rodrigues/11/a99/a43

She graduated in Fine Arts at ESBAL (Lisbon). Between 1989 and 1992, she lived in Berlin where she specialised in Aesthetics and Artistic Communication, at Hochschule der Kunst TU.

She holds a PhD in Architecture (Visual Communication), is Head of the Department for Drawing and Visual Communication, and is full Professor at the Faculty of Architecture - University of Lisbon.

As an academic researcher, she is interested in the cognitive processes of the act of drawing and its specificity as a mode of non-verbal communication.

Published several books.

Ana Leonor M. Madeira Rodrigues is also an artist who exhibits regularly and since the $90 \mathrm{~s}$ is investigating and recording a self-created/invented bacteriological accident, that alters the relationship between closed inhabited spaces (kitchens) and their inhabitants: the Burned By Blue collapse.

She works on this accident since then.

Two recent exhibitions: My Laboratory - Luanda, Angola. Compulsive Acts of Communication between Bacteria and Humans, Library of the College of Science 
Ana Maria Martinho Gale Senior Researcher, CHAM, FCSH, Universidade NOVA de Lisboa, Lisbon, Portugal

\author{
Ana Marta Feliciano \\ Senior Researcher, (CIAUD) Centro \\ de Investigação em Arquitectura, \\ Urbanismo e Design-Faculdade \\ de Arquitetura - Universidade \\ de Lisboa, Lisbon, Portugal
}

\section{Annalisa Di Roma \\ Associate Professor in Industrial Design, Polytechnic University of Bari}

\author{
António Leite \\ Senior Researcher, (CIAUD) Centro \\ de Investigação em Arquitectura, \\ Urbanismo e Design - Faculdade \\ de Arquitetura - Universidade \\ de Lisboa, Lisbon, Portugal
}

Member of CIAUD

Member of CAA - College of Art Association

Member of ASCI - Art and Science Collaborations

Responsible for the Journal for Drawing "Linha do Horizonte

http://linhadohorizonte.fa.utl.pt/

She has supervised postgraduate students across the world (including in the United States, Angola, Portugal, Cabo Verde and Mozambique). A number of her postgraduate students have attained positions in academia and politics.

Having been involved in over fifty international missions, she visited multiple times all five Lusophone African countries. She also has established academic links with Brazil, South Africa, Argentina, Venezuela, Botswana, Canada, and the United States, has lectured extensively in many of these locations.

She serves on the editorial board of 4 international academic publications. Since 1990, she has authored 71 publications; books, editions, book chapters, international papers.

Her current research focuses on one monograph project: Material Culture and Literature in Sub-Saharan Africa, as well as on two papers for peerreviewed publications.

Born in Torres Vedras, Degree in Architecture from the Faculty of Architecture of the Technical University of Lisbon in 1995, worked in the City Hall of Torres Vedras between 1996 and 1997, also exercising professional activity in Architecture and Urbanism.

In 2001 obtained the Master Degree in Housing Architecture from the Faculty of Architecture of the Technical University of Lisbon, with the dissertation "Habitação e Utopia nos Anos Sessenta; As Propostas do Grupo Archigram no Contexto de uma Década de Rupturas".

Between 2003 and 2007 hold a scholarship from the Foundation for Science and Technology and attended the PhD course Teoría y Practica del Proyecto in the Polytechnic University de Madrid. Obtained the European Doctorate in Architecture in 2008, with the thesis "La Metáfora del Organismo en las Arquitecturas Visionarias de los Años Sessenta; La Obra del Grupo Archigram como Reinvención de un Nuevo Habitar".

Since 1997, is professor and researcher at the Faculty of Architecture of the University of Lisbon, teaching theoretical and practical disciplines of Architectural Project.

Writes on Art and Architecture. Books:

- A Metáfora do organismo nas Arquitecturas dos Anos Sessenta; a Obra dos Archigram como manifesto de um novo habitar (ed. 2014; ISBN 978-989-658-264-7)

- A Casa Senhorial como Matriz da Territorialidade; a Região de Torres Vedras entre o Tempo Medieval e o final do Antigo Regime (ed. 2015; ISBN 978-989-658-335-4).

Since December $2016 \mathrm{PhD}$ Associate Professor in Industrial Design, since December $2008 \mathrm{PhD}$ Assistant professor in Industrial Design (S.S.D. Icar-13) at the Polytechnic of Bari. Enrolled at Architects Council of Taranto, n. 604.

In 2005-2007-Post-PhD Fellowship; in 2004 - PhD in Architectural Design; 2000-Graduated in Architecture. She has obtained many acknowledgements, prizes and mentions in the field of applied activity in the architectural project and industrial design for international and national competitions.

The main research interests, from $\mathrm{PhD}$, are focused on updating the language of the artefacts, from the artistic industry issues until the digital industry and craft; particularly she has focused the cultural heritage. Actively involved in the Apulia Regional industrial and creative districts.

Degree in Architecture from the Faculty of Architecture of the Technical University of Lisbon in 1995, professional exercise since 1995 is responsible for several projects of Architecture and Urbanism.

In 2001 received the degree of Master of Housing Architecture in the Architecture Faculty of the Technical University of Lisbon. Between 2003 and 2007, was research fellow of Foundation for Science and Technology, obtaining in 2008 the degree of 'European Doctor' conferred by Polytechnic University de Madrid, with the thesis "La Casa Romántica; de la Matriz Romántica a un Concepto Acrónico y Operativo en la Contemporaneidad". 
Barbara Vaz Massapina

Senior Researcher, (CIAUD) Centro de Investigação em Arquitectura, Urbanismo e Design - Faculdade de Arquitetura - Universidade de Lisboa, Lisbon, Portugal
Calogero Montalbano

Professor at the Polytechnic of Bari in Architectural and Urban Design
Carla Alferes Pinto

Senior Researcher CHAM, FCSH, Universidade NOVA de Lisboa, Lisbon, Portugal
$\mathrm{He}$ is professor and researcher at the Faculty of Architecture of the University of Lisbon since 1996/1997, teaching theoretical and practical disciplines of Architecture Project, taught project workshops of Urban Planning and Architecture in seminars in Portugal and abroad.

Writes for Art and Architecture publications, of which stand out the books A Casa Romântica; uma Matriz para a Contemporaneidade (ed. 2014; ISBN 978-989-658-263-0)) and A Casa Senhorial como Matriz da Territorialidade; a Região de Torres Vedras entre o Tempo Medieval e o final do Antigo Regime (ed. 2015; ISBN 978-989-658-335-4).

Made her Architect's degree in 1994, Master's degree in Housing Architecture 2002 entitled "TA: Shelter Typologies. Home's proposal for the Homeless" and her PhD in Architecture in 2011 entitled "Brise-soleil in Architecture", all graduated from the Faculty of Architecture, Technical University of Lisbon. The PhD thesis was awarded the SIL Prize for Development and Investigation.

Started her professional activity in 1989 while still a student in a private architectural office, working as a designer under the supervision of a senior architect.

In 1994stayed in this office as a trainee architect, and worked as a coauthor on different projects in Architecture and Urban Design, some of them awarded with $1^{\circ}$ Prize in the International Competition for Cacilhas downtown planning, the $1^{\circ}$ Prize for Unit 5 in the Vila Expo in Lisbon and the $1^{\circ}$ Torres Novas City Prize for Rehabilitation. In 1994 starts to teach 1st and 2nd year of architecture in a private University. In 1999 began an academic carrier at the Faculty of Architecture, University of Lisbon, having taught Project to all the five years, as well as Conservation and Rehabilitation studies, Urban Planning and Design, and Interiors Architecture. Full Professor for the Department of Architecture, and an effective member of CIAUD (Research Centre for Architecture, Urbanism and Design, Faculty of Architecture, University of Lisbon). Author or co-author of several papers presented at national and international congresses and seminars. Co-author of seven published books on the subject of Architecture and/or Conservation Studies.

Architect received his $\mathrm{PhD}$ in Architectural Design in 2002. He is since 2008 an aggregate professor at the Polytechnic of Bari in Architectural and Urban Design. Member of Retevitruvio, Italian inter-university network of ssd icar/14/15/16 (since 2010). Member of the Academic Board of the $\mathrm{PhD}$ in "Architectural design for the Mediterranean countries" (2010-12). Elected member of the Academic Senate at the Polytechnic of Bari (2012-15). Elected member of the "Strategic Committee" of the Polytechnic of Bari (2013- 15). Member of the Academic Board of the $\mathrm{PhD}$ "Architecture: Innovation And Heritage" (since 2013). Member of the Italian National Committee of ICOMOS International Council on Monuments and Sites, Italian National Council of Monuments and Sites (since 2014). Member international Committee of ENHR - European Network for Housing Research (since 2015). Reviewer in the International Journal "Journal of Civil Engineering and Architecture Research" (since 2015). Deputy Rector of the Polytechnic of Bari for the new University Library System (since 2015). His research is based on the technical and technological updating of settlement and housing building techniques. He is author or co-author of 68 scientific papers in the context of Urban Enhancement of Cultural Heritage and Sustainable Development in Urban scale. He has also published seven academic books, and he took part in over 16 design competitions. $\mathrm{He}$ took part in over seven international and 17 national programs. $\mathrm{He}$ is the inventor of one filed patent in the area of recycling and innovative sustainable buildings.

Postdoctoral Fellowship (SFRH/BPD/100597/2014: "The Allure of Things. The Consumption of Artistic Objects by the 'Infantas' and Queens of the Avis-Beja dynasty (1430-1577)".

$\mathrm{PhD}$, History of Art/Museology and Artistic Heritage: "The Collection of Colonial Art of the Lisbon Patriarchate. Proposal for Study and Museum Display" 
Carla Chiarantoni

Professor in Architectural Design at the School of Building Architecture of the Polytechnic of Bari

\author{
Carla Sofia Alexandrino Pereira \\ Morgado \\ Senior Researcher, (CIAUD) \\ Centro de Investigação em \\ Arquitectura, Urbanismo \\ e Design - Faculdade de \\ Arquitetura - Universidade \\ de Lisboa, Lisbon, Portugal
}

\section{Carlos Berriel}

Instituto de Estudos da

Linguagem - UNICAMP, Brazil

\author{
Carlos Figueiredo \\ Senior Researcher, (CIAUD) Centro \\ de Investigação em Arquitectura, \\ Urbanismo e Design-Faculdade \\ de Arquitetura - Universidade \\ de Lisboa, Lisbon, Portugal
}

My research focus is on the production, circulation, and consumption of art throughout the Early Modern period.

In the last years I have been dedicated to the analysis of gender issues associated with demand, production and appropriation of material culture; the study of the artistic relations between Portugal and India (16th-17th centuries) and the ways in which material culture produced in such contexts was used; and on the discussion of the reception and representation of "Indo-Portuguese art" in Portuguese museums (19th-20th centuries).

Engineer received her PhD in Building Engineering in 2005. Since 2011, she is an aggregate professor in Architectural Design at the School of Building Architecture of the Polytechnic of Bari. Her fields of research and teaching are focused on building design and study of sustainable solutions in residential project of affordable housing and social housing; designing systems using renewable energy technologies in a residential project. Since 2011, she is Masters' Degree advisor for final studios on architectural and urban design at the Polytechnic of Bari.

Architect holding an MSc in Contemporary Architectonic Culture (FA-TU Lisbon), Doctor in Urbanism (ETSAB/UPC, Barcelona), post-doctoral studies and Habilitation for Full Professorship in Urbanism. Since 1997, she lectures at the Lisbon School of Architecture, University of Lisbon; courses include urban design studios, contemporary urbanism and metropolitan studies. Actively involved in networks and research, recent positions include being an expert at the H2020 Societal Challenges 6 .

He is professor at the University of Campinas, in Brazil, editor of the academic journal Morus - Utopia e Renascimento, currently in the 10th issue, and coordinator of U-TOPOS- Centro de Estudos sobre Utopias. He held postdoctoral researches at the Università La Sapienza (Rome, 1996/7), Università degli Studi di Firenze (2006-7) and was Visiting Professor at the Dipartimento della Scienza dello Stato of the Università di Firenze (2015). He is the author of several papers on Brazilian literature and utopias. He is presently preparing an edition of the Città del sole, by Tommaso Campanella.

Academic Position: Assistant Professor. Faculty of Architecture, Lisbon University

Main Research Fields:

- VisualCommunication, FictionalCinematicVisualNarrativesinDocumentary, Film and Animation

- Screenwriting and Conceptual Design, Media and Communication, Production Design, Scenography and Architecture

- Computer Graphics and Digital Tools of Project and Design, in its conceptual and representation components

- Material and Intangible Heritage, Identity, Memory and Society

Teaches in the 1st Cycle Degrees of Urban Planning, Architecture, Set Design, Design and Fashion Design and has a Degree in Architecture in the Faculty of Architecture of UTL (1986).

Short CV:

Post-Graduation:

- EU sponsored Course in "Informatics applied to Architecture and Urbanism", in FA-UTL, in 1987, being approved with a Distinctly Approved rating

- Post-graduation in Architecture of Housing, in 1998-9, being approved with 18 values, in the Faculty of Architecture of UTL

$\mathrm{PhD}$ :

- In Communication Sciences, conferred by the University of Beira Interior, in 2008, under a dissertation entitled "Scenic and Film Space: Representation and Computer Graphics", approved unanimously by the Jury.

Main Contact (email): cfigpt@gmail.com/cfig@fa.ulisboa.pt

Contact (phone): (+351) FA-UL 213615859 (extension 425859) 
Clara Gonçalves

CITAD, Universidade Lusíada de Lisboa, Portugal/ISMAT, Portugal

Cristina Figueiredo

Senior Researcher, (CIAUD) Centro de Investigação em Arquitectura, Urbanismo e Design - Faculdade de Arquitetura - Universidade de Lisboa, Lisbon, Portugal

Fátima Vieira

Senior Researcher, CETAPS,

Faculdade de Letras da

Universidade do Porto
Degree in Architecture, 1993, FA/UTL | Master in Architecture, 1998, FA/ UTL | Doctorate in Architecture, 2008, ETSA/US | Researcher, s. 2010, CITAD, FA/ULL | Member of ATINER, s. 2014 | Associate professor of Architecture and History and Theory of Architecture, s. 2008, ISMAT, Portimão | Author of published articles in several magazines on architecture | Copy-editor of Jornal Arquitectos, 2000-2003 and 20102012 | Practicing architect, s. 1995 |

1995 to date - Assistant Professor of the Faculty of Architecture of Lisbon University

2006 - PhD in Biotechnology at I.S.T./U.T.L., on topic: Development of a System of Biodegradation oxic - anoxic for Textile Wastewater, Lisbon/ Portugal on 21/12/2006.

1999 - MSc in Biotechnology/Biochemical Engineering from IST/UTL, Lisbon/Portugal

1993 - Lic th in Textile Engineering (Production Branch) by U. Beira Interior, Covilhã/Portugal

1999-2006 - Member of ENVERG (Environment Research Group) IBB - IST/UTL

2007 to date - an Effective member of CIAUD (Research Centre for Architecture, Urbanism and Design), FA/ULisboa.

Research Areas of Interest: Textile Materials, Sustainable Textiles and Apparel, Biotechnology, Ecodesign.

2008-2012 - Coordinator of the Master in Fashion Design FA/UTL

2009 to date - Scientific Evaluator ANI (National Innovation Agency)

2007 to date - Scientific Advisor at the PhD in Design:

- The importance of biotechnology application in the textile industry: Natural textile dyes, public examination on 29/04/2016, Very Good with Praise

- New Materials and Techniques Applied to White Castle Embroidery Design in Textiles and Clothing, public examination on 12/06/2012, Very Good with Praise.

- Sustainability in Apparel Design, public evidence in 07/03/2013, Very Good with Praise.

Co-Advisor of the Scientific Research Project PhD in Design:

- Intelligent Clothing as a Tool to Design of Sports Performance, public evidence in 18/10/2012, Very Good with Praise.

Associate Professor (with "Agregação") at Faculdade de Letras da Universidade do Porto, where she has been teaching since 1986. She is the Chairperson of the Utopian Studies Society /Europe since 2006. At ILCML - Instituto de Literatura Comparada Margarida Losa, she was the Coordinator for the three editions of the research project "Literary Utopias and Utopian Thought: Portuguese Culture and the Western Literary Tradition" (2001-2010) funded by FCT (Fundação para a Ciência e a Tecnologia) and is now the Coordinator of the multidisciplinary research project (also funded by the FCT) "Utopia, Food and the Future: Utopian Thinking and the Construction of Inclusive Societies - A Contribution from the Humanities". Fátima Vieira is also the director of the collection "Nova Biblioteca das Utopias", of the Portuguese publishing house "Afrontamento", and the director of E-topia, an electronic journal on Portuguese utopianism since 2004 (http://ler.letras.up.pt/site/ default.aspx?qry=id05id164\&sum=sim), as well as of Spaces of Utopia, a transdisciplinary electronic journal on Utopia written in English (since 2006 - http://ler.letras.up.pt/site/default.aspx?qry=id05id174\&sum=sim). She is also Book Review Editor for the North-American Journal Utopian Studies (edited by Penn State) since 2006.

From 2008 to 2010, Fátima Vieira coordinated the outreach project "Eurotopia 2100: An Interactive Project" (http://web2.letras.up.pt/eurotopia/), which involved more than 4,000 students of all ages who were invited to imagine what will the future be like. She is now the coordinator of "PANUtopia 2100: An Interactive Project "(http://panutopia.oxys.pt/), which is focused on the imagination of the diet of the future and on its repercussions on other aspects of the society, and also of "Utopia 500", a multievent programme for the commemoration of the 500th anniversary of the publication of Thomas More's Utopia. 
Fernando Moreira da Silva Senior Researcher, Director of (CIAUD) Centro de Investigação em Arquitectura, Urbanismo e Design - Faculdade de Arquitetura Universidade de Lisboa, Lisbon, Portugal

Giacomo Martines

Researcher in Architectonical Restoration - Polytechnic of Bari

\author{
Gianni Montagna \\ Senior Researcher. (CIAUD) Centro \\ de Investigação em Arquitectura, \\ Urbanismo e Design - Faculdade \\ de Arquitetura - Universidade \\ de Lisboa, Lisbon, Portugal
}

Giovanni Leoni

Full Professor of History

of Architecture at the

University of Bologna, Italy

Gisela Horváth

Faculty of Arts and Humanities, Partium Christian University, Oradea, Romania

Hervé Baudry

Senior Researcher of CHAM, FCSH, Universidade NOVA de Lisboa, Lisbon, Portugal
In 2013, the American and Canadian association Society for Utopian Studies selected Fátima Vieira as a recipient of the Larry E. Hough Distinguished Service Award.

Fátima Vieira has given many lectures in Portugal and abroad, has organised several international conferences, and has edited and contributed to several volumes in her main fields of study.

Full Professor in Design at the Faculty of Architecture of the University of Lisbon (FA/ULisboa). MSc and PhD - University of Salford, UK; PhD - Technical University of Lisbon; Post-Doctorate from the University of Salford; President of CIAUD - Research Centre for Architecture, Urbanism and Design; Coordinator of the Design Scientific Area, Coordinator of the Masters and PhD degree in Design at FA/ULisboa; Member of the General Council of the University of Lisboa; Panel coordinator for the PhD and post-doc Scholarships in Design, Architecture and Urbanism at FCT; International consultant for CNPq, Brazil; Honorary Researcher at SURFACE, UK; Cocoordinator of the International $\mathrm{PhD}$ degree in Design and Innovation (general coordination of the University of Naples); Visiting Professor at several foreign universities in Brazil, Italy and Spain; Supervisor of 78 Master Dissertations and $48 \mathrm{PhD}$ theses; Member of Scientific Committees of international scientific journals; Coordination and participation in funded scientific research projects; Publications in indexed scientific journals with peer review in data basis such as Scopus and ISI; several book chapters and three books, published by editors such as Caleidoscópio or Taylor \& Francis.

$\mathrm{He}$ is University Researcher in Architectural Restoration at the Bari Polytechnic since 2009, PhD in Environmental Design.

Professor for the "Restoration" course in Architecture Degree Course and the "Restoration Work-site" in the Specialization School. His main research theme is upon the valorisation of the heritage. Was responsible for Bari Polytechnic in the project "Archeology of the Landscapes of Puglia Adriatic in Roman times". Is the author of texts on landscaping and historical centres restoration

PhD. in Design by the Faculty of Architecture of the University of Lisbon since 2012, with a thesis on the application of smart systems to clothing, teaches Fashion Design at the first academic year of the Masters in Fashion Design and often teaches other disciplines at the same institution, as in the case of Accessory Design. In the textile development laboratory (D_TEX) of the Faculty of Architecture of Lisbon, he is responsible for the area of Textile Design and is responsible for the discipline of Laboratory III of the PhD in Design of the same Faculty. $\mathrm{He}$ is a guest lecturer at the Doctoral Program in Fashion Design at the University of Minho in collaboration with the Beira Interior University, where he collaborates in the teaching of "Interfaces Design Fashion and Technology".

Giovanni Leoni (b. 1958; Ma/PhD IUAV, Venice, Italy) is Full Professor in History of Architecture at the University of Bologna (www.unibo.it/ sitoweb/giovanni.leoni). He coordinates the PhD Program in Architecture (PhD.unibo.it/Architettura/it). His main fields of research are art and architecture theory in the 19th century, particularly John Ruskin; Post War architecture, particularly in Italy and in Portugal.

Professor at Partium Christian University, Oradea, Romania. She teaches aesthetics and philosophy of art, mainly for fine arts students. Her main interest is in the discussions of challenges of contemporary art. In the previous 20 years, she held management positions within her university. She is one of the head organisers of international Argumentor Conference. She wrote five books in Hungarian, and she published several articles on the philosophy of art.

(b. 1957, Neuilly-sur-Seine, France) is a senior researcher at the CHAM. He completed a PhD degree in French Renaissance Studies in 1989 and obtained the HDR in 2012.

His main investigations are about the History of Book, Science and Censorship. Last book published Livro médico e censura, Lisbon: CHAM, 2017. 


\section{Committees}

Iolanda Ramos

Senior Researcher, CETAPS,

Universidade Nova de Lisboa-

Faculdade de Ciências Sociais

e Humanas

Jorge Boueri

Universidade de São Paulo,

Faculdade de Arquitetura e

Urbanismo, Faculty Member

\section{João Cabral}

Senior Researcher, (CIAUD) Centro de Investigação em Arquitectura, Urbanismo e Design - Faculdade de Arquitetura - Universidade de Lisboa, Lisbon, Portugal

João Luís Lisboa

Senior Researcher, Vice-Director of CHAM, FCSH, Universidade NOVA de Lisboa, Lisbon, Portugal
Professor at Universidade Nova de Lisboa, Portugal. She has published extensively within the field of Victorian Studies, mainly on political, economic and gender issues under the framework of Cultural Studies and Utopian Studies. The Gulbenkian Foundation published her doctoral thesis on Ruskin's social and political thought in 2002. She is the author of Matrizes Culturais: Notas para Um Estudo da Era Vitoriana (Colibri, 2014) and co-editor of Performing Identities and Utopias of Belonging (Cambridge Scholars Publishing, 2013). Her essay "Tell me what you like, and I'll tell you what you are' - An Overview of the Victorian Political Economy of Art" (2003) was published in Cahiers Victoriens et Édouardiens, a journal indexed in Scopus. She is a member of the Editorial Board of the online and double blind-refereed journals The Eighth Lamp: Ruskin Studies Today and Spaces of Utopia: An Electronic Journal. She has been carrying out research as part of the project "Mapping Dreams: British and North-American Utopianism" within the CETAPS (Centre for English, Translation and Anglo-Portuguese Studies).

Architect, Urbanist and Designer. Full Professor at the University of São Paulo | Brazil.

Visiting Professor at Osaka City University, 2005, and the University of Lisbon, 2014-2015. He wrote four books on architecture dimension and housing.

He held several positions in the Public Administration of cities and produced several works of Urban Planning and Design.

$\mathrm{He}$ is architect (Escola Superior de Belas Artes, Lisbon), Honours Diploma Urban and Regional Development Planning (Architectural Association, London), PhD (Urban and Regional Studies, University of Sussex, U.K.) is associate professor at the Faculty of Architecture (FA), University of Lisbon and researcher at the Research Centre for Architecture, Urbanism and Design. At FA he is currently president of the Department of Arts, Humanities and Social Sciences. He is also the coordinator of the "Colégio dos Urbanistas" at "Ordem dos Arquitectos". His research interests and teaching activities range from urban planning, policies and methodologies to regional development, territorial governance, and spatial planning systems. He has been involved in research projects on governance and policies in urban regions. Recent relevant publications include Crespo, J. L. \& Cabral J. (2012) "The institutional dimension to urban governance and territorial management in the Lisbon metropolitan area" in Seixas J. \& Albet A. (ed.) Urban Governance in Southern Europe, Ashgate; and Cabral, J. (2015) Portugal, disP - The Planning Review, 51, Taylor \& Francis.

$\mathrm{PhD}$ in History and Civilization, European University Institute, Florence, (Mots (dits) écrits. Formes et valeurs de la diffusion des idées au 18ème siècle au Portugal).

2001-2002, Director of the Portuguese Institute for the Book and Libraries, Ministry of Culture

2004-2014, director of the Centre for the History of Culture.

Fields of research: Intellectual History, History of the book and reading, Modern European culture.

Some recent publications:

2016: "From publishing to the publisher - Portugal and the changes in the world of print in the 19th century" in Abreu and Silva (eds.), The Cultural Revolution of the 19th century: Theatre, the Book-trade and Reading in the Transatlantic World, London, I.B.Tauris Publ. (69-86 and 260-261).

2015: "Read, watch and laugh (with 18th-century humorous books)" in Ferrão and Bernardo (eds.) Views on Eighteenth-Century Culture: Design, Books and Ideas, Cambridge, CSP (346-357).

2011: "Ideas in (to) facts" in Irimia and Ivana (eds.), Author(ity) and the Canon between institutionalization and questioning: Literature from high to late modernity, Bucharest, ICR (144-152).

2009: "Facts being..." Storia della storiografia, 55, pp. 3-28. 
João Paulo Oliveira e Costa Senior Researcher, President Centre of CHAM, FCSH, Universidade NOVA de Lisboa, Lisbon, Portugal
João Seixas

Physics Department of Instituto Superior Técnico (Lisbon, Portugal)। Member of Laboratório de Instrumentação e Física Experimental de Particulas (LIP)/Member of Centro de Física Teórica de Particulas (CFTP)/Member of CMS Collaboration
$1998 \mathrm{PhD}$ in History, FCSH/NOVA University, Lisbon, Portugal.

1989 MSc in History

1984 Graduated in History, Faculty of Letters, University of Lisbon, Portugal.

Historian and novel writer, he is a professor and senior researcher with main scientific interests being the Renaissance and the European Maritime Discoveries.

1990-... Professor, Department of History, FCSH/NOVA University, Lisbon, Portugal.

2002 Director of CHAM (NOVA FCSH_UAc), Lisbon, Portugal.

2013-... Coordinator of the E-learning Master Program in History of the Portuguese Empire, FCSH/NOVA University.

2013-... Member of the Scientific Council of FCSH/NOVA University

2016-... Head of UNESCO Chair for Maritime Heritage

RESEARCH PROJECTS (selected)

2005-2015 Coordinator of the project EVE - Enciclopédia Virtual da Expansão Portuguesa (POS-C 7092/4.2/C/REG). http://www.fcsh.unl.pt/ cham/eve/

2000-2015 Editor of Bulletin of Portuguese Japanese Studies (2000-2009) and Director of Anais de História de Além-Mar (2003-).

2000-2008 Coordinator of the FCT funded research projects "Nobility in the India State in the 16th century" (POCTI/36414/HAR/99 e POCTI/ HAR/55685/2004 2000-2008) and "Portuguese Jesuits missions in the Far EasT” (POCTI/HAR/66684/2004 - 2004-2008).

PUBLICATIONS (selected)

2014 (book) (coordinator and co-author with José Damião Rodrigues and Pedro Aires de Oliveira), História da Expansão e do Império Português, Lisbon, Esfera dos Livros.

2013 (book) Mare Nostrum, em busca de honra e riqueza, Lisbon, Temas \& Debates (includes a chapter on the 15th-century donations of Atlantic Islands, which were not yet discovered).

2011 (book chapter), "The beginnings of Portuguese Overseas Expansion" in The Historiography of Medieval Portugal c. 1950-2010 (ed. José Mattoso), Lisbon, Instituto de Estudos Medievais, pp. 591-606

2009 (book) Henrique, o Infante, Lisboa, Lisbon, Esfera dos Livros.

2006 (book) D. Manuel I, um príncipe do Renascimento, Lisbon, Temas \& Debates.

$\mathrm{He}$ is a Professor in the Physics Department of Instituto Superior Técnico (Lisbon) and researcher at the Particle Physics Laboratory (LIP). He is the Leader of the Portuguese Team in the NA60 Collaboration of the SPS Program at CERN and Team Leader of the Heavy Ions and Quarkonia Group in the CMS Collaboration of the Large Ion Collider (LHC) Program also at CERN. He has been a resident researcher at CERN and professor and researcher at several other institutions in Europe and outside Europe. He has authored more than 400 scientific publications in high impact journals and a book. He also has an important scientific outreach activity both in Portugal and abroad with regular presentations on Particle Physics for the public and schools.

Besides his research work in theoretical and experimental Particle Physics, he also works in new energy efficiency methods and implementation of renewable energies in urban areas. He is responsible for pioneering studies in this scientific domain in Portugal.

More recently, he has participated in the creation of an innovative didactic product (Euclides Box for the company Geometric World) aiming at radically changing the way students, parents and professors see geometry and Mathematics. 


\section{Committees}

Jorge de Novaes Bastos

Senior Researcher, (CIAUD)

Centro de Investigação em

Arquitetura, Urbanismo e

Design - Faculdade de Arquitectura
Full Professor at Faculdade de Arquitectura, Universidade de Lisboa 1. Academic background -

(a) Ph.D. (1987) - The University of Texas at Austin, Austin, TX, USA;

(b) M.Sc. (1983) - The University of Texas at Austin, Austin, TX, USA;

(c) Diplome (1978) - Universidade do Porto, Oporto, Portugal;

2. Professional activities - Rehabilitation projects (some studies)-

A.1. - PUBLIC SPACES -

A.1./01 - Palácio dos Marqueses de Fronteira e de Alorna, Benfica - Lisboa, 1990-97

A.1./02 - Palácio de Pancas - Palha, Sta. Apolónia - Lisboa, 1991-94

A.1./03 - Adega dos Frades, Mosteiro de Santa Maria da Vitória - Batalha, 1994

A.1./04 - Picadeiro d' El - Rei, Praça - Forte de Almeida - Almeida, 1994

A.1./05 - Centro de Interpretação da Estação Arqueológica de Milreu Algarve, 1996

A.1./06 - Arco Romântico do Parque de Monserrate - Parque Natural de Sintra - Cascais, 1998

A.1./07 - Centro de Interpretação do Parque Ecológico, CIPE, Monsanto Lisboa, 1999-00

A.1./08 - Casa Rural do Séc. XVI, Estação Arqueológica de Milreu Algarve, 1999-00

A.1./08 - Termas da Ferraria, São Miguel - Região Autónoma dos Açores, 2000

A.1./09 - Termas do Carapacho, Graciosa - Região Autónoma dos Açores, 2001

A.1./10 - Residência Nuno Vitorino, Quinta do Texugo - Sampaio, 2001

A.1./11 - Residência de Estudantes, Fábrica da Pólvora, Barcarena-Oeiras, 2003

A.1./12 - Recuperação da Envolvente do Jardim da Trv. do Hospital, Lisboa, 2004

A.1./13 - Fortaleza de Sagres - Túnel de Acesso e Torreão Central - Algarve, 2004-05

A.1./14 - Torre de Água, Jardim da Alameda Roentgen - Lisboa, 2004-05

A.2. - PRIVATE SPACES -

A.2./01 - Casal da Beloura, São Pedro de Penaferrim - Sintra, 1989

A.2./02 - Edifício de Habitação, Rua Ribeiro Sanches, Lapa - Lisboa, 1990-97

A.2./03 - Refeitório da Fábrica de Linhas COATS \& CLARK - Vila Nova de Gaia, 1993

A.2./04 - Casa da Várzea, Trescova - Felgueiras, 1996

A.2./05 - Casa de Santa Cruz em Felgar - Moncorvo, 1998

A.2./06 - Prédio na Rua de São Mamede ao Caldas - Lisboa, 1999

A.2./07 - Residência na Quinta de São João, Fontaínhas - Cascais, 2000-04

Senior Lecturer of English at Partium Christian University, Oradea, Romania, received her doctorate from West University of Timișoara in 2012. The title of her thesis is "Reading and Watching Jane Austen: Pride and Prejudice and Sense and Sensibility," and it discusses the major film adaptations made based on the literary classic's two novels in the light of intermediality. Having written her dissertation on the transposition of Jane Austen's first two novels on film, her publications focus on the question of fidelity in film adaptations of literary classics and how various novelistic elements have been transposed onto the screen in adaptations of Austen's novels. Other interests in adaptations of literary classics involve recent audiobooks of rewritings of Shakespeare's Hamlet and Romeo and Juliet. Her publications also include the article "When in Rome, Do as the Romans Do: Power Game in Hannibal" published in Displacing the Anxieties of Our World: Spaces of the Imagination (ed. Ildikó Limpár. Cambridge Scholars Publishing).

Her research interests include translation studies with special focus on audio-visual translation. She also works as a dubbing translator from English to Hungarian, and translated, among others, the film adaptations of Tom Jones, and Bright Young Things. 
Jorge Firmino Nunes

Researcher, (CIAUD) Centro de

Investigação em Arquitetura,

Urbanismo e Design - Faculdade

de Arquitetura - Universidade

de Lisboa, Lisbon, Portugal

Julian Sobrino Simal

Profesor Titular de Universidad

Universidad de Sevilla (Escuela

Técnica Superior de Arquitectura)

Luis Bernardo

Senior Researcher, CHAM, FCSH,

Universidade NOVA de Lisboa,

Lisbon, Portugal

Luís Crespo Andrade

Senior Researcher, CHAM, FCSH, Universidade NOVA de Lisboa, Lisbon, Portugal

Łukasz Rudecki

Faculty of Arts - Kazimierz Pulaski University of Technology and Humanities in Radom
She has been teaching at Partium Christian University since her graduation in 2005. Presently, her classes include Morphology and Syntax and English Language Methodology courses as well as practical courses on writing, public speaking and audio-visual translation. She is also the Head of the Teacher Training Programme of Partium Christian University.

He graduated from the Faculty of Architecture of Lisbon Technical University in 1993, where he obtained his $\mathrm{PhD}$ in Architecture in 2012, with the thesis A Razão da Arquitectura: A Ideia de Metrópole nos Pensamentos de Manfredo Tafuri e Rem Koolhaas. He teaches at the Department of Arts, Humanities, and Social Sciences of the Faculty of Architecture of Lisbon University. Projects Editor of Journal Arquitectos (2002-2005 e 2009-2012). He was part of the editorial team of Ordem dos Arquitectos between 2005 and 2007. Coordinator, with Ana Vaz Milheiro and João Afonso, for the exhibition Habitar Portugal 2003-2005 (2006 Architecture Venice Biennale). Researcher of the project Arquitecturas do Mar at the Faculty of Architecture of Lisbon University, supported by the Foundation for Science and Technology.

Doctor in History of Art and Full Professor of the Technical School of Architecture of the University of Seville. He teaches in the Master of Architecture and Heritage and is part of the Doctorate of Architecture Program. He is a specialist in the History of Industrial Architecture and Systems of Interpretation of Industrial Heritage. Among his publications, we can emphasise "Arquitectura industrial en España, 1830-1990", "Arquitectura de la industria en Andalucía" y "Luces sobre la memoria. La Real Fábrica de Artillería de Sevilla". He is Vice-President of TICCIH-Spain.

Professor in the Department of Philosophy of NOVA University's Faculty of Social and Human Sciences; main teaching, searching and publishing fields: Philosophy of Knowledge, Hermeneutics, Philosophy of Culture; he's currently Assistant Vice-Dean on the area of Curriculum Management and Teaching Assessment and Head of the Master degree in Teaching Philosophy; Researcher at CHAM, from which he is also one of the Vice-Directors responsible for the publications. Co-Director of Cultura - Revista de História e Teoria das Ideias, he has published several books, papers and translations concerning the eighteenth and twentieth centuries. He is particularly interested in the way texts, and discourses intend to define the direction of Modernity. For further references: http:// fcsh.unl.pt/faculdade-en/docentes/blmav_en.

Professor in the Department of Philosophy of the Faculdade de Ciências Sociais e Humanas of the Universidade Nova de Lisboa.

Coordinator of the Early Modern and Modern Thought Group of CHAM. Coordinator of the Seminário Livre de História das Ideias.

Author of numerous studies on utopian thought and intellectual history, namely Intellectuals, Utopia e Comunismo. A inscrição do marxismo na cultura portuguesa (Lisbon, Fundação Calouste Gulbenkian - Fundação para a Ciência e a Tecnologia, 2010).

Was born in 1979 in Radom. Graduate of the Department of Art of the Technical University of Radom (currently Faculty of Arts at the University of Technology and Humanities in Radom). Diploma in Prof. Aleksander Olszewski's studio of painting. Annexe to the diploma in Prof. Krzysztof Wyzner's studio of Graphic Techniques. He had 12 solo exhibitions (Kielce, Radom, Siedlce, Szczecin, Łódź, Magdeburg, Warszawa) and participated in ca. 70 group exhibitions (among others in Berlin, Częstochowa, Koszyce, Toruń, Rzeszów, Szczecin, Warszawa, Zakopane). Three-time winner of the exhibitions. In 2009, after he had defended his doctoral dissertation entitled N-FIGURES. Concrete reality, allusion and symbol in my paintings, he was awarded a $\mathrm{PhD}$ degree in visual arts. At present, he holds the position of Assistant Professor in the Department of Painting and Drawing at the Faculty of Arts of the University of Technology and Humanities in Radom. 


\author{
Marco Neves \\ Researcher, (CIAUD) Centro de \\ Investigação em Arquitectura, \\ Urbanismo e Design - Faculdade de \\ Arquitetura - Universidade de Lisboa, \\ Lisbon, Portugal
}

\author{
Margarida Vaz do Rego Machado \\ Universidade dos Açores, CHAM \\ e FCSH
}

Holds a PhD in Design from the Faculty of Architecture, University of Lisbon, where he is an Assistant Professor. He is also a full member of the Research Centre for Architecture, Urbanism and Design, of the same Faculty and a contributor member of the Research Centre for Planning, Architecture and Design, Lusíada University, Lisbon.

His research focuses on the relationship of interaction, user experience and data visualisation with print and digital media.

Graduated in History at the Faculty of Letters, University of Lisbon, obtained, in 2001, her $\mathrm{PhD}$ in the area of Modern History at the University of the Azores, with the thesis $A$ wealth of the Old Regime. The commercial house of Nicolau Maria Raposo d'Amaral, published in 2006 by Patrimonia. She is Assistant Professor of the School of Social Sciences and Humanities - Department of History, Philosophy and Arts of the University of Azores. In this University coordinates the master of Insular and Atlantic History (XV to XX centuries).

Researcher at the CHAM, coordinated the line: Overseas Economies and Trade Networks. At this moment coordinates the core of the Azores of the same Center (CHAM - Azores).

She has dedicated her study to Azores economy and society, with particular focus in the eighteenth-century and the Mercantile Elites and Slave trade. At the moment, she is part of the international research group on Atlantic system of Iberian tobacco (XVII-XIX centuries. She regularly participates in conferences, in Portugal and abroad, with specialised papers.

Full Professor. Teacher of History, History of Culture and History of Science (18th-21th centuries) - 1st, 2nd and 3rd Bologna cycles. Supervises PhD students, Master Students; Scientific Coordination of 1st cycle: history and sources methodologies work; Director and scientific coordination of the Unit Research (R\&D) History and Philosophy of Science Unit (CEHFCi) www.chefci.org (www.officinalis.org). President of the Advanced Research Scientific Board (IIFA) - Évora University (2010_1013). Cocoordenation of the network History \& Science with the IHC (Institute of Contemporary History-UNL)

Conducting Post-Doctoral Research at CHAM. Professor at Lusíada University of Lisbon. PhD in Portuguese Studies (King's College, 2008). Published The Literary Institution in Portugal since the Thirties: An Analysis under Special Consideration of the Publishing Market (Peter Lang, 2010). Research interests include contemporary Portuguese literature, utopias, and the publishing market of novels

Professor Maria João Durão has a Doctoral Degree in the area of Colour and Space, and Post-Doc funded by FCT in Art, Science and Technology -Drawings of Calatrava. She lectures Drawing and Architectural Drawing at the Faculty of Architecture UL, holds scientific responsibilities in Doctoral Course of Design and created the first 'Master Degree in Colour for Architecture' UTL. She coordinates the Colour Lab-FA and the Colour and Light Research Group, both of the University of Lisbon.

http://labcor.fa.ulisboa.pt/

http://www.apcor.org

http://www.spacearchitect.org

PhD History, Master Sociology.

Professor at Faculty of Architecture University of Lisbon. Member of the Department of Arts, Humanities, and Social Sciences. Main domains of teaching and research: Applied Social Sciences, Humanities, Art and Architecture History, Design, Scenography, Heritage. Since 1978scientific research experience and professional consulting in the domains of Social Sciences and Humanities. Member of the Scientific Board Faculty of Architecture (2008-2011; 2014...). Senator of The University of Lisbon, elected for the Scientific Board (2013-2017). Effective member CIAUD - Research Centre for Architecture, Urbanism and Design faculty of Architecture, University of Lisbon, associated member of CHAM. Member of the Geographical Society - Lisbon, president of the Arts and Literature Section, and in 2016 also the Section of Heritage Studies, vowel of the sections: Tourism, Communication Studies, Education and Ethnology. Author of several indexed texts in Isis, Scopus, Web of Science 
Maria da Luz Sampaio

Research Member of CIDEHUS $P h D$ in History of Science specialisations in Museology in University of Évora

Maria Leonor Garcia da Cruz Professor and Researcher at Faculty of Arts and Humanities of the University of Lisbon, Lisbon, Portugal

Maria Leonor Sampaio da Silva Senior Researcher, Universidade dos Açores, CHAM e FCSH

Maria Luísa Malato

Senior Researcher, ILCML Faculdade de Letras, Universidade do Porto
Graduated in History in the Faculty of Humanities from the University of Porto 1997; post-graduation in Social Museology at the University of Lusófona, Lisbon. Later on, in 2009 I have finished my Master in Local and Regional Studies in the Faculty of Arts and Humanities of the University of Porto. Recently, on 6 July 2015, I have accomplished my $\mathrm{PhD}$ in History of Science specialisations in Museology in University of Évora, with the title "From the factory to the Museum: identification, heritage and diffusion of technical-industrial culture".

From 1992, I was involved in the research project of the Inventory of Industrial Heritage of the city of Porto. In 1996, I was involved in the plan and opening of the Museum of Science and Industry of Porto, and later on, from 2000 to 2011 I was its Director. I have a long-standing interest and much experience in cultural management (especially museums), and in the studies of industrial material culture. I have started in 2014 a training Course "Introduction to Industrial Tourism" in the Faculty of Arts and Humanities of Porto. Since 2013 Research Member of CIDEHUS - University of Évora. Since November 2016 Post-Doc CIDEHUS/ University of Évora. Author of books and papers about local history, conversion of Industrial buildings, museum plan, industrial heritage.

Professor and Researcher at Faculty of Arts and Humanities of the University of Lisbon-FLUL. PhD. in Early Modern History (UL 1999).

Researcher in Early Modern History and European Overseas Expansion, Maghreb, Asia and America, supervising master thesis, PhD. and postdoctoral dissertations in societies, mindsets, institutions, political and financial management, representations.

Member of the Research Units Building and Connecting Empires and Cultural Encounters and Intersecting Societies at the History Centre UL, she supervises research projects in IMAGETICS: interdisciplinary studies on representations and identitarian constructions, and TREASURY: history of economic thought and management, taxation, social networks, politics and ethics.

Publications in RCAAP and in international journals indexed as Vozes dos Vales (Qualis-Capes, Latindex) and O Ideário Patrimonial (DRJI, Latindex).

https://lisboa.academia.edu/MariaLeonorGarciaCruz/CurriculumVitae

She is a Professor at the Faculty of Social Sciences and Humanities at the University of the Azores, where she teaches courses related to Translation and Portuguese and English Contemporary Culture. She holds a Master's degree in Anglo-Portuguese Studies and a $\mathrm{PhD}$ in English Culture. She has dedicated her research to English authors such as H. G. Wells and Bertrand Russell, and to themes that bridge Literature, Culture, Translation and the Visual Arts. She is a Researcher at CHAM and has been involved in research projects concerning the cultural relevance of photographic documents. Besides several articles on the main academic fields of her research (utopian and science fiction writing, translation studies and dialogues of literature with other arts) her publications include a book on the Arts Academy of the Azores, several annotated translations of travel books by foreign authors who visited the Azores in the 19th century, and a book of short stories with which she was awarded in 2014 the Humanities Prize Daniel de Sá.

Associate Professor with tenure at the University of Porto (Faculty of Literature and Arts, Porto, Portugal) for rhetoric, and aesthetics. MA and $\mathrm{PhD}$ in Comparative Literature and Aggregation in Romance Literatures (2008). Main fields of research: Utopian Studies, Rhetorical Studies, and Theatre (18th-19th centuries). Since 1990, member of the French Society for Eighteenth-Century Studies (SFEDS). Member of the Institute of Comparative Literature Margarida Losa (). Since 2013, Vice-President of the Portuguese Comparative Literature Association (APLC). Co-Editor of Pontes de Vista, an online journal about Literature and Philosophy. From her bibliography, we could highlight the following books:

A Little anthology of Portuguese Poems, Porto, Cena Poétrica/Poetria, 2016. 
Maria do Rosário Monteiro

Senior Researcher. Coordinator of the Research Group Culture and Literature, CHAM, FCSH, Universidade NOVA de Lisboa, Lisbon, Portugal

Maria do Rosário Pimentel

Researcher, CHAM, FCSH, Universidade NOVA de Lisboa, Lisbon, Portugal

Mário Say Ming Kong

Professor/Researcher, CIAUD - FAUL, Lisbon School of Architecture, Lisbon University, Lisbon, Portugal/CHAM, FCSH, Universidade NOVA de Lisboa Secção de Desenho, Geometria e Computação, Departamento de Artes, Humanidades e Ciências Sociais, Faculdade de Arquitectura, Universidade de Lisboa, Portugal

Olinda Kleiman

Professor at Sorbonne NouvelleParis 3
«O Belo e os Monstros, in O Teatro em Portugal nos séculos XVIII e XIX, eds. Ch. Müller e M. Neumann, Berlim/ Lisboa, Ibero-Amerikanisches Institut, 2015, pp. 39-61;

L'Exil et le Royaume: d'Albert Camus à Vergílio Ferreira, Paris, Le Manuscrit, 2014, 240 pp. Co-editor;

Uma História da Literatura Europeia, Lisboa, Quid Juris, 2008;

Le XVIIIe Siècle: une Époque d'Ombres et de Lumières. Co-author, Mons/ Belgium, Univ. Mons, 2009;

Manual Anti-Tiranos, Porto Alegre/ Brazil, 2009.

Professor of Comparative Literature at the FCSH/UNL (New University of Lisbon). Graduated in Modern Languages and Literature at the University of Lisbon (1983), Master in Comparative Literary Studies by the Universidade Nova de Lisboa (1987) and PhD in Literary Sciences, speciality of Comparative Literature, by Universidade Nova de Lisboa (1997). Lectures Comparative Culture and Literature in graduate and postgraduate levels. Senior Researcher at CHAM. Editor of several books, both in Portuguese and English, author of the first academic books on Tolkien published in Portugal, and author of several essays on Utopia, Fantasy, and Science Fiction. Further information: Full CV: http://www.degois.pt/visualizador/curriculum. jsp?key=4279105572167475.

Maria do Rosário PIMENTEL graduated in History at Universidade de Coimbra and was awarded her PhD in Portuguese Studies at Universidade Nova de Lisboa. She is currently Associate Professor at Universidade Nova de Lisboa. She has carried out activities predominantly in the area of Cultural History and Society with a particular focus on Cultural topics, Slavery and the Slave Trade. She has published, among other works and papers, Viagem ao Fundo das Consciências. A Escravatura na Época Moderna. Lisboa, Colibri, 1995 (338 pages), which is a version of her $\mathrm{PhD}$ thesis, and Chão de Sombras. Estudos sobre Escravatura, Lisboa, Colibri, 2010 (200 pages).

She is currently a researcher in the fields of Portuguese Culture and History of Slavery and is a senior researcher at CHAM. Member of, Sociedade Portuguesa de Estudos do Século XVIII, and its international branch, Sociedade Internacional de Estudos do séc. XVIII, as well as with the Portuguese Committee for the UNESCO Project Slave route. Author of two monographies on slavery, editor of 5 proceedings on Portuguese Culture and Literature, and more than 20 articles published in national and international journals.

Degree in Architecture at FAUTL, PhD Professor with Aggregation in Architecture in the field of drawing and visual communication at Escuela Superior Technical Architecture Barcelona - Universidad Politécnica de Cataluña (UPC-ETSAB). He is presently PhD Professor at FAUTL, Lecturer in ESELx and Visiting Professor at the Master Course in arts at ESBAL.

Previously taught at Lusophona University (ULHT) and Independent University, respectively in the Departments of Urban Planning and. Architecture.

In 2000 was Coordinator of the first year of the course in Urban Planning ULHT In 1998 Regent of the discipline Design/CAD/Geometry in ULHT.

He participated in scientific research studies and consulting work for outside entities. He has also participated in several publications, communications Indexed to TAYLER \& FRANCIS, Thomson Reuters, ISI, Web of Knowledge, Web of Science, ELSEVIER Products, SCOPUS, CrossRef, ProQuest, EBSCO, and training courses to disseminate the results of his research activities at national and international universities.

His primary research areas are Harmony and proportion in representation between West and East and its application to Sustainable Architecture, in particular by applying concepts of origami and Kirigami to materials such as paper and bamboo. 
Paulo Pereira

Researcher, (CIAUD) Centro de Investigação em Arquitetura, Urbanismo e Design - Faculdade de Arquitetura - Universidade de Lisboa, Lisbon, Portugal

Pedro Cortesão Monteiro

Researcher, (CIAUD) Centro de Investigação em Arquitectura, Urbanismo e Design - Faculdade de Arquitetura - Universidade de Lisboa, Lisbon, Portugal

Raffaella Maddaluno

Researcher, (CIAUD) Centro de Investigação em Arquitectura, Urbanismo e Design - Faculdade de Arquitetura - Universidade de Lisboa, Lisbon, Portugal

Santi Centineo

Polytechnic University of Bari
Art and architecture historian, Master in Art History (Univerdidade Nova de Lisboa), PhD in History of Architecture (Faculdade de Arquitectura da Universidade de Lisboa) with the thesis A Fabrica Medieval. Concepção e construção na arquitectura portuguesa, 1150-1550 (2012)

Invited lecturer in several academic meetings and seminars in Portugal, Spain, France (CNRS), Germany, Italy, U.S.A (George Washington University) and Brazil (USP). Curator of several exhibitions in Portugal and abroad Vice-President of IPPAR (National Heritage) between 1995 e 2002. Editor and author of História de Arte Portuguesa, (3 vols, Círculo de Leitores). Author of Lugares Mágicos de Portugal (8 vols.), Círculo de Leitores, 2004-2005. Co-curator of the international exhibtion Neue Welten (Novos Mundos), held in the Deutsche Historisches Museum, Berlin (2007/2008). Author of Arte Portuguesa. História Essencial (Temas \& Debates, 2012) and Decifrar a Arte Portuguesa (6 vols Círculo de Leitores, 2014) Teacher in Faculdade de Arquitectura da Universidade de Lisboa.

(Lisbon, 1965), got his Architect's degree from FAUP (Oporto, 1990) and a Master in Product Design from the same faculty (1998). PhD in Design by FAUL (Architecture Faculty, Lisbon University) in 2014, with a thesis entitled "The Design Question: in-definitions and misunderstandings between form, fame and function". Lecturer in Design courses at Universidade Lusíada (since 1995) and FAUL (since 2009). Works sporadically as an architect and designer.

Graduated in Architecture at the Faculty of Architecture at the Polytechnic of Bari in 2000. Gained a $\mathrm{PhD}$ in Architectural History during the course of Architecture and Construction at the Faculty of Engineering of the University of Tor Vergata in Rome in 2007 with a degree in architectural history entitled: THE HOUSING ESTATE OF INACASA MARIO AND RIDOLFI WOLFGANG FRANKL IN CERIGNOLA: ANALYSIS AND INTERVENTION STRATEGIES.

Obtained a specialisation grant for study abroad in 2002 funded by the Polytechnic of Bari, at the Faculty of Architecture of the University of Porto (FAUP).

Attended a Master Second-level short specialisation degree in CONSERVATION, MANAGEMENT AND ENHANCEMENT OF INDUSTRIAL HERITAGE at The University of Padua with a thesis entitled VALORIZATION PROPOSALS OF INDUSTRIAL HERITAGE IN VAL DI BISENZIO: ISOLA WOOL MILL CASE STUDY. A HISTORICAL, ARCHITECTURAL AND TERRITORIAL GOVERNANCE ANALYSIS.

In 2012-2013 became a fellow of the Calouste Gulbenkian Foundation in Lisbon with a research project aimed at the publication of a book in Italian on FERNANDO TÁVORA: A VIAGEM DO GULBENKIAN 1960 and 2014 in the same Foundation with the theme of MILLING FACTORIES IN PORTUGAL, THE ROUTES OF WHEAT, FLOUR AND PASTA IN THE TRANSITION TO MODERNITY 1860-1930.

An Assistant Professor and Fellow at the Faculty of Architecture of the University of Matera in Basilicata from 2008 to 2011 in the courses of HISTORY OF THE CITY AND LANDSCAPE, GENEALOGY OF THE LABORATORY OF ARCHITECTURAL HISTORY, HISTORY OF ARCHITECTURE and an assistant on the course in the HISTORY OF CONTEMPORARY ARCHITECTURE at the Faculty of Architecture of the Polytechnic of Bari in 2003 and 2004.

Currently, she is Assistant Professor at the Faculty of Architecture of The University of Lisbon in the courses of HISTORY OF THE MODERN ARCHITECTURE and THEORY OF DESIGN.

Architect, graduated with full marks from Palermo University, specialised at Milan Teatro alla Scala, PhD in Interior and Exhibit Design at Politecnico di Milano under Andrea Branzi's tutorship.

He works as set-designer in many italian theatres (such as Maggio Fiorentino, San Carlo di Napoli, La Fenice di Venezia, Carlo Felice di Genova, Comunale di Bologna, Verdi di Trieste, Petruzzelli di Bari, Regio di Torino) and abroad (Montpellier, Città del Mexico, Philadelphia, Tokyo, Avignone, Toulouse, Madrid, Burgos, Coruña, Bilbao, Santiago de Compostela, Tenerife, Salamanca). 
Teresa Botelho

Researcher, CETAPS, DLLM, FCSH, Universidade NOVA de Lisboa, Lisbon, Portugal
In 2006 for Mozart's Don Giovanni at Genoa Carlo Felice, he is awarded "Pierluigi Samaritani Award" as best Italian young set-designer.

$\mathrm{He}$ is the author of many publications and essays over the interior, exhibit, furniture and set design.

$\mathrm{He}$ is an assistant professor of Interior, Furniture and Exhibit Design at Politecnico di Bari.

She is Associate Professor at The Faculty of Social and Human Sciences, Nova University of Lisbon, where she teaches American Studies. She has published extensively on African American, and Asian American culture and literature, theatre and drama. Her current interests include technological utopias/dystopias and the post-human, post-black literature, identity theory in its intersection with utopia, visual culture and cinema, the collaboration between sciences and literature, especially drama, and literary and visual representations of $9 / 11$ with a particular emphasis on Arab-American literature and televisual fiction.

Her most recent publications include:

- "Utopía y poder en Estados Unidos: Una unión más perfecta: utopías de pluralidad en los Estados Unidos." Utopía y poder en Europa y América. Ed. Moisés González García and Rafael Herrera Guillén. Madrid: Tecnos Editorial, 2015 pp. 251-268

- "Reimagining the Body in Post-Singularity Techno-Utopias" Spaces of Utopia: An Electronic Journal, 2nd series, no. 3, 2014 pp. 70-83-

Performing Identities and Utopias of Belonging. Ed. Teresa Botelho/ Iolanda Ramos. Newcastle: Cambridge Scholars Publishing, 2013

- "Dystopias of Belonging: Defamiliarizing Sameness in Danzy Senna's Symptomatic" Performing Identities and Utopias of Belonging. Ed. Teresa Botelho/Iolanda Ramos. Newcastle: Cambridge Scholars Publishing, 2013 pp. 52-68

- "Finding an Aesthetic of her Own: Partnering Identities in the Work of Faith Ringgold" Women and the Arts: Dialogues in Female Creativity. Ed. Diana V. Almeida. Bern: Peter Lang, 2013 pp. 109-124

- "Becoming Tony Alfama: The American Education of a Portuguese Kid in Charles Reis Felix' Tony: A New England Boyhood.” Gávea-Brown: A Bilingual Journal of Portuguese-American Studies Vol. XXXIV-XXXV, 2013 pp. 131-146.

Professor and Coordinator of the master degree in Communication Design in the Faculty of Architecture at the University of Lisbon (FA-ULisboa) where she teaches Graphic Design, Communication Design, Typography and Infographics, since 2003.

Permanent Researcher at the CIAUD - Centro de Investigação em Arquitectura, Urbanismo e Design of the FA-ULisboa.

Profissional practice in Graphic and Editorial Design since 1987.

\section{PEER REVIEW}

Scholars have been invited, through an international CFP, to submit full chapters on theoretical and methodological aspects related to the theme "Modernity: Frontiers and Revolutions" in the scientific fields of Architecture, Arts and Humanities, Design, Engineering, Social and Natural Sciences. The selected chapters where then publically presented on the Congress "MODERNITY: FRONTIERS AND REVOLUTIONS" thus fostering a multidisciplinary discussion.

All full chapters proposals were subjected to double-blind peer review, distributed according to each scientific area to senior researchers for evaluation. Members of the scientific committee also peer-reviewed papers within their field of expertise. The theme had been proposed to the international academic community in October 2017, during PHI Congress in Bari, Italy. This book is the outcome of the production, revision, lengthy selection and evaluation process that lasted 12 months.

\section{BOOK PRODUCTION REPORT}

Nearly one hundred full papers were submitted. After the selection, the Reader will find in this book chapters written by authors (senior researchers and post-graduation students) from Brazil, Canada, Finland, Hungary, Israel, Italy, Romania, Poland, Portugal, Russia, Spain, Sweden, Ukraine, United Kingdom and the U.S.A. 


\section{Sponsors}

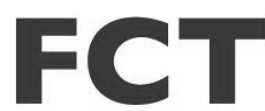

Fundação para a Ciência e a Tecnologia

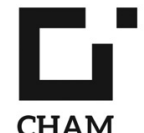

CENTRO DE HUMANIDADES NOVA FCSH-UAC
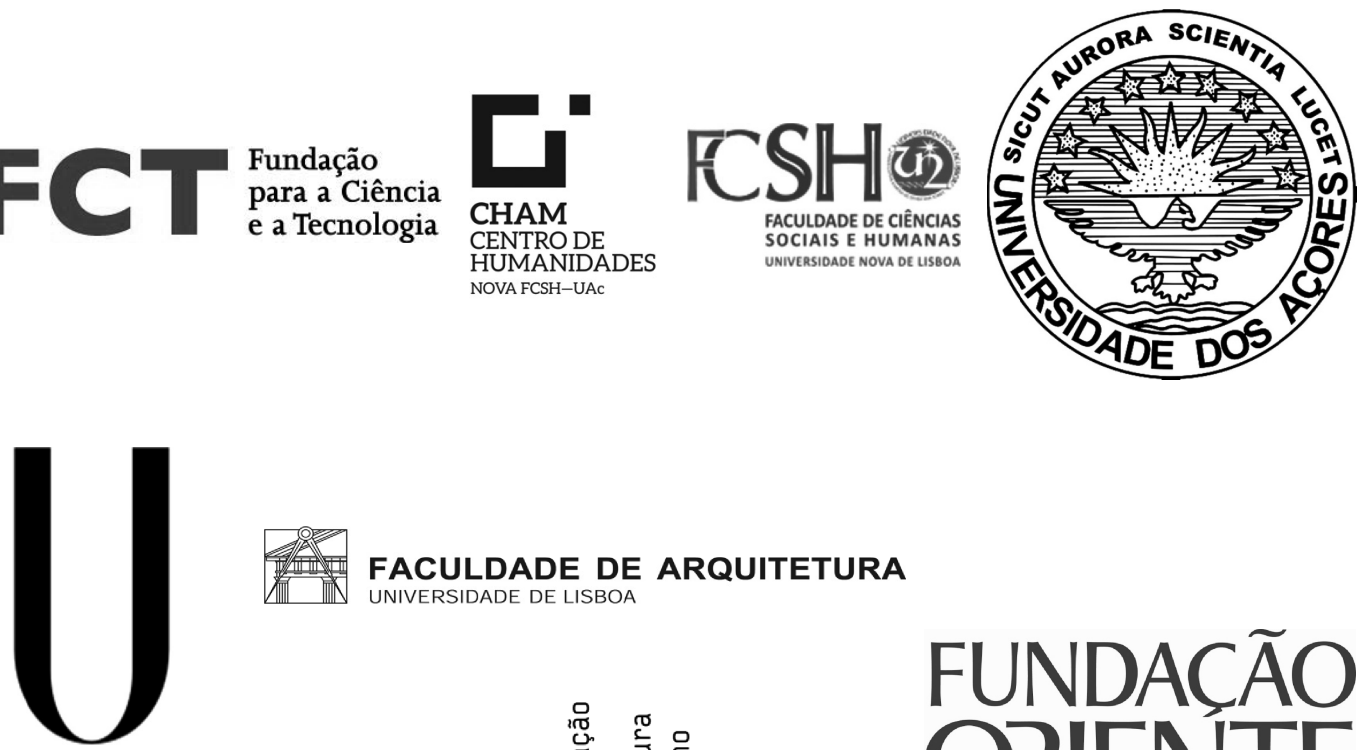

LISBOA

FACULDADE DE ARQUITETURA

UNIVERSIDADE DE LISBOA

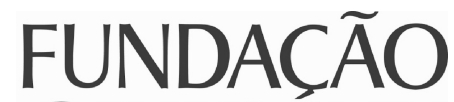

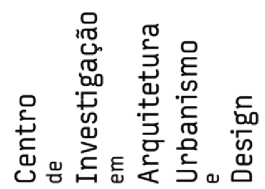

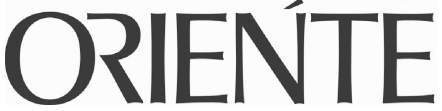

UNIVERSIDADE

DE LISBOA

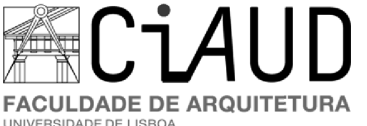

This event and this book had the support of CHAM (NOVA FCSH-UAc), through the strategic project sponsored by FCT (UID/HIS/04666/2013). 
$\because$ Taylor \& Francis

Taylor \& Francis Group

http://taylorandfrancis.com 


\title{
Introduction
}

\author{
Mario S. Ming Kong \\ CIAUD - FAUL, Lisbon School of Architecture, Lisbon University, Lisbon, Portugal \\ CHAM, FCSH, Universidade NOVA de Lisboa, Lisbon, Portugal \\ Secção de Desenho, Geometria e Computação, Departamento de Artes, Humanidades e Ciências Sociais, \\ Faculdade de Arquitectura, Universidade de Lisboa, Portugal
}

The positive aspects of modernity are to be acknowledged unreservedly: we are all grateful for the marvellous possibilities that it has opened up for mankind and for the progress in humanity that has been granted to us.

Pope Benedict XVI

Wo damals die Grenzen der Wissenschaft waren, da ist jetzt die Mitte. ${ }^{1}$

Georg Christoph Lichtenberg (1742-1799)

Revolutions are the locomotives of history. ${ }^{2}$

Karl Marx (1818-1883)

The theme "Modernity, Frontiers and Revolutions" is a subject that raises questions.

What do we understand by being modern, what is it to be modernist and where do the boundaries between the two concepts reside?

Where do the current frontiers reside and how do they fit into a modern or modernist view of the world? We live in an age where technology bridges physical distances and brings the four corners of the earth closer, but at the same time new ideological, religious, and economic barriers emerge that create new, and reinforce old, frontiers.

To be modern is to be in tune with the latest expressions of society in science, culture and technology. Being modernist is, from the analysis of the actuality and its problems, to propose new approaches, which in many cases include the disruption of the status quo and can lead to revolutions.

Keywords: Modernity, Frontiers, Revolutions

\section{MODERNITY; FRONTIERS AND REVOLUTIONS}

Referring to our reality as modern is common. The term is already so rooted in our language that it has become synonymous with contemporary - in fact, it coexists in the same period characterised by the social, cultural and economic reality of the world.

1. "Where once the frontier of science was is now the centre." (Lichtenberg, 1998: 181). Author's translation.

2. In Karl Marx Quotes. (n.d.). BrainyQuote.com. https:// www.brainyquote.com/quotes/karl_marx_166482. Retrieved March 29, 2018.
Most of all, Modernity is the fruit of the construction of human thought about the facts that have developed throughout history and, in a way, it applies to all the movements that drive changes in society.

The concept of modernity as an ideology or a way of perceiving the world is associated with the theoretical thinking of René Descartes (1596-1650). This French philosopher was noted above all for his revolutionary work in the fields of philosophy, where his works are seen as a source of inspiration and a basis for the construction of modern philosophy - as is the case of Discours de la Methode (Descartes, 1637, 537); in science, by stipulating that the way to be taken for the con- 


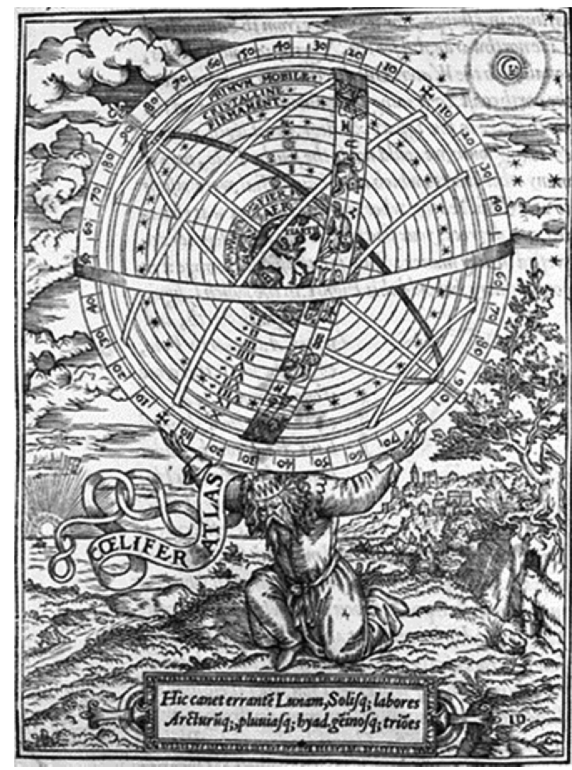

Figure 1. Atlas bearing the heavens in the form of an armillary sphere from William Cunningham, The Cosmographical Glasse, London, 1559. The verse at the bottom of the engraving is from Book I of Virgil's Aeneid, in which Atlas is referred to as a teacher of astronomy. In Site: http://www.sites.hps.cam.ac.uk/ starry/armillpoems.html

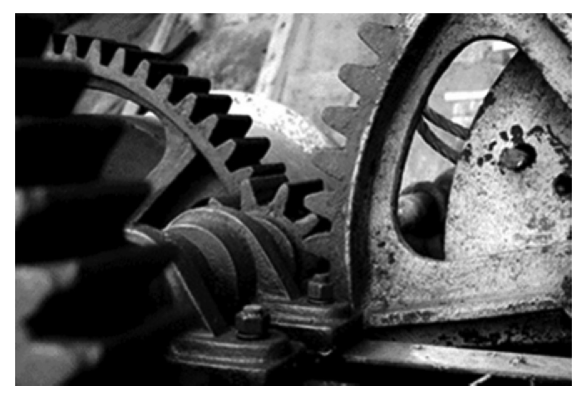

Figure 2. Gear of disused machinery of a quarry. Source: https://commons.wikimedia.org/wiki/File:Ingranaggio.jpg, on 09:17, 8 August 2008.

struction of scientific knowledge is the evidence, the analysis, the synthesis and the enumeration; and in mathematics for suggesting the merging of algebra with geometry - a fact that generated the analytical geometry and coordinate system that now bears its name.

Rational thinking and the Cartesian method paved the way for the events that are seen as the starting point of the modern era, as in the case of the industrial revolution which motivated a series of changes in European society leading to great ideological and military conflicts at the beginning of the 20th-century.

Rational thought has thus overlapped traditional thinking, linked to theology and religion, opening the way for new approaches and reflections on society and the world. The sociologist Max Weber (1864-1920) referred to this phenomenon as the process of "Entzauberung de Welt"3 (Weber, 1919: 488), - the disenchantment of the world - in which the modern subject has put aside customs and beliefs established in the secular traditions that were based on the preconceived ideas. Thus, the explanations and questions anchored in the use of instrumental reason came to break the notions that were previously pre-established and grounded in the spiritual core.

The first disorder which the modern world encountered with the abandonment of some religious principles, which supported social customs and organisations, was the driving force for what the sociologist Zygmunt Bauman (1925-2017) referred to as being one of the elementary characteristics of modernity: the "Quest for order" (Bauman, 1998: 281-287). This quest had already been announced by Thomas Hobbes (1588-1679), in his work Leviathan (1651) written during the English Civil War (1642-1651). In this work, Hobbes explores his views on human nature and the need for a sta-

3. "Die zunehmende Intellektualisierung und Rationalisierung bedeutet also nicht eine zunehmende allgemeine Kenntnis der Lebensbedingungen, unter denen man steht. Sondern sie bedeutet etwas anderes: das Wissen davon oder den Glauben daran: daß man, wenn man nur wollte, es jederzeit erfahren könnte, daß es also prinzipiell keine geheimnisvollen unberechenbaren Mächte gebe, die da hineinspielen, daß man vielmehr alle Dinge - im Prinzip - durch Berechnen beherrschen könne. Das aber bedeutet: die Entzauberung der Welt. Nicht mehr, wie der Wilde, für den es solche Mächte gab, muss man zu magischen Mitteln greifen, um die Geister zu beherrschen oder zu erbitten. Sondern technische Mittel und Berechnung leisten das. Dies vor allem bedeutet die Intellektualisierung als solche" (Weber, 1919: 488).

[Increasing intellectualisation and rationalisation does not therefore mean an increasing general knowledge of the conditions of life under which one stands. But it means something else: the knowledge of it or the belief in it: that one could, if one wanted, experience it at all times, that in principle there are no mysterious, unpredictable powers that play into it, that one rather - in principle - could control by calculation all things. However, that means the disenchantment of the world. No longer, like the savage, for whom there were such powers, one must resort to magical means to control or solicit the spirits. Nevertheless, technical means and calculation do that. Above all this means the intellectualization as such.] Free translation by the author. 
ble government and society, describing the power that a sovereign state should have as a controller of its subjects and responsible for strengthening order, specifying what was acceptable or what was repulsive.

However, it was only in the 19th and 20th-centuries that this phenomenon took on the dimensions we see today. The modern era, faced with increasingly global conflicts, was marked by the segregation of classes, individuals and, above all, of nations. Bauman writes on this subject the following:

Modernity may be best described as the age marked by constant change - but aware of being so marked. In other words, modernity is an era conscious of its historicity. (1993: 592)

The modern States, as we know them, were formed on this logic of exclusion and inclusion. The conflicts between socially accepted ideas and everything that is different is the hallmark of modern societies. The marking act, to which Bauman refers, is the principle of the determination of an order. By excluding what is not part of an organisation, we simultaneously establish what part of it is. As a clear example, we have the borders of countries that precisely delimit the extent of territory and still serve as an invisible barrier for the "foreigners" or those who are not part of that order. In particular, this separation was strengthened during the twentieth-century and the global wars that followed, such as World Wars I and II, and continue to this day, being the current crisis within the European community caused by the torrent of refugees from the Middle East and Africa, one of the most striking examples.

Another remarkable feature of the modern era is that the pursuit of progress followed the establishment of order. In this sense, the wars were responsible for the vertiginous technological advance of the last century. The race for the supremacy of war equipment has led to the development of new technologies also applied outside the military context that have changed again the way we see the world we live in.
Facing the long trajectory that we strive to cover, we can contemplate the extent of the complexity of how human thought and social organisations evolved. Understanding historical processes allow us to understand the origin of the reality in which we live. The modern world is continuously reinventing itself and changing, and like all the times that have come before, the time will come for a new understanding of what is modern in the world. It remains for us to ask: what will this world be like?

\section{BIBLIOGRAPHICAL REFERENCES}

Bauman, Zygmunt (1993) Modernity and Ambivalence. Oxford: Polity Press.

—. (2000), Liquid Modernity, Polity Press, UK.

Descartes, René(1637)Discoursdelaméthode, Lieud'édition Leyde, Pays-Bas. Site: https://fr.wikisource.org/wiki/ Livre:Descartes_-_Discours_de_la_m $\%$ C3\%A9 thode,_\%C3\%A9d._1637.djvu.

Hobbes, Thomas (1651) Leviathan, or The Matter, Form and Power of a Common-Wealth Ecclesiastical and Civil. London: Printed for Andrew Crooke.

Marx, Leo; Mazlish, Bruce. (1996) Progress. Fact or illusion? Michigan: University of Michigan.

Colquuhoun, Alan (2004), Modernidade e tradição clássica: ensaios de arquitetura. São Paulo: Cosac \& Naify.

Ellul, Jacques (1968) A técnica e o desafio do século. Rio de Janeiro: Paz e Terra.

Giddens, Anthony (1990) The Consequences of Modernity. Cambridge: Polity.

Kurz, Robert. (1991) Der Kollaps der Modernisierung: Vom Zusammenbruch des Kasernensozialismus zur Krise der Weltökonomie. Frankfurt am Main: Eichborn.

Lichtenberg, Georg Christoph. (1998) Schriften und Briefe, 6. Auflage. 2nd volume, Munich: Wolfgang Promies.

Prigogine, Ilya; Stengers, Isabelle (1997) The End of Certainty. The Free Press. ISBN 978-0-684-83705-5.

Weber, Max (1919) Wissenschaft als Beruf. In: Geistige Arbeit als Beruf. Vier Vorträge vor dem Freistudentischen Bund. München: Erster Vortrag.

. (1971) Burocracia. In: Ensaios de sociologia. $2^{\mathrm{a}} \mathrm{ed.}$ Rio de Janeiro: Zahar. 
$\because$ Taylor \& Francis

Taylor \& Francis Group

http://taylorandfrancis.com 
Part I

Modernity: Frontiers and revolutions 
$\because$ Taylor \& Francis

Taylor \& Francis Group

http://taylorandfrancis.com 


\title{
Know how and cultural context: From ideas to facts and from facts to ideas
}

\author{
Manuel Silva \\ Departamento de Informática e Ingeniería de Sistemas (DIIS), Instituto de Investigación en Ingeniería de \\ Aragón (I3 A), Universidad de Zaragoza, Spain
}

\begin{abstract}
Based on the know-how, technology is not only culture but a powerful cultural engine. A central element in some cultural revolutions, technology cannot be considered in Isolation. Terms like utopia, progress, innovation, frontiers, and revolutions are briefly considered. The exposure will mainly be from an engineering perspective. We record certain facts. Because not so well known, several of them are taken from the engineering history of Spain. Moreover, some questions are raised as food for thought. Certainly, we are living in times of (r)evolutions, and new objectives for the humankind and the "blue planet" should be designed and implemented.
\end{abstract}

Keywords: Technological progress, technological predictions, engineering, cultural inertia, limits, revolutions

\section{TRYING TO PLACE OURSELVES IN THE CONTEXT}

Utopia(s), progress (ses) and revolutions are related concepts. Obviously, "related" does not means synonymous, neither the relations always express any kind of monotonicity property. These multiform relations can be perceived analysing the number of times that, for example, the terms "progress" or "revolution" appear in a text on "utopia" (or any other permutation among all three).

Even if "utopia" suggests utter perfection, utopian thinking may be dangerous as it may motivate people to do anything and everything in service of - in cases - its admittedly impossible goals. There have been religious and secular utopian ideas that lead to crimes against humanity!

Scholar debates about what is or not a "revolution" are very open, in particular depending on the considered time scale dimension. In political settings, it may be accepted that all (most?) revolutions where "first a thought in one man's mind." Nevertheless, if we think of revolution as an "evendriven almost immediate" important change, then neither the Neolithic or Agricultural Revolution, the wide-scale transition of several human cultures, nor the Industrial Revolution are revolutions. They are processes that extend for more or less long time but represents drastic changes for humanity. A pertinent question is: the so-called Industrial Revolution was a planned change in one man's mind? It is well known that among many other confluences (technological, organisational, financial, etc.), the Industrial Revolution starts with local desires of improving some techno-economical activities (for example, to draw water from a mine ${ }^{1}$ ). In addition, it is often assumed that the new technology gave birth to the "factory system," but some historians point to its appearance as a change in the social control of production (A. Pacey, 1974).

The idea of "progress" is a concept that should be considered from many different perspectives (it is essentially multidimensional, and many criteria can be used for its assessments: technology, science, social organisation, maintenance or improvement of environment...). In intellectual history, progress refers to the idea of improvements in the human condition. So in the leading countries of the industrial revolution, the tens of thousands of artisans and farmers transformed in proletarians who worked at least $12 \mathrm{~h}$ per day in dark, humid or polluted factories and industrial facilities did experience an improvement in the quality of their lives? Moreover, what about the environmental consequences?

Also related, and planned for a next issue of this PHI series on Proportion, (Dis)Harmony and Identity is innovation. To "innovate" is basically to "make changes in something established, especially

1. Not in the context of that revolution, to draw water from a mine with a steam machine happens in Spain at the beginning of the xvii century with Jerónimo de Ayanz Beaumont that in 1606 register a multiple privilege (N. García Tapia, 1992); nearly one century later, in England, the machine of Thomas Savery (registered in 1698) precedes the Thomas Newcomen Steam engine (1712), that clearly symbolizes the beginning of the Industrial Revolution. 
by introducing new methods, ideas, or products" (Oxford Dictionary). In this context, an innovation may be (and it has been the case) to construct at latitude $30^{\circ}$ a small variation of a building designed for $60^{\circ}$ of latitude, in steel with large glass surfaces to obtain a greenhouse effect! The obvious consequence is that no AC system can make the building habitable in summer (but not only). This is why the concept has frequently been "coloured" a posteriori with the idea of "improvement," adding the constraint of providing "better solutions." Anyhow, the notion of innovation as improvement has different perspectives. From the engineering point of view, what is mainly valued is the "intrinsic technical novelty" of a mechanism, machine, process or organisation that improves the efficiency, the quality of the performed work, the dependability, the sustainability, etc. From the economic point of view, innovation is more related to any new entrepreneurial policy that leads to "real increase diffusion in the market", perhaps due to the increase of the demand, as Joseph A. Schumpeter claim. In other words, it is not the "intrinsic" technical "novelty", but its "success" on the market. ${ }^{2}$ Furthermore, it is well known that the better technical product is not always the preferred by the market. The reason is that many other conditions as marketing or financial strategies or technical "openness" (e.g., the availability to interact with other systems) may be more relevant (think for example in the market distribution versus technical quality of personal computers some three decades ago).

\section{A POINTILLIST AND BIASED PERSPECTIVE WITH ENGINEERING AS BACKDROP}

To deal with frontiers and revolutions in a general setting is a very ambitious endeavour. Terms as utopia, fantasy, audacity, progress, creativity, social and knowledge constraints, etc. may appear more or less interleaved. Like in pointillism, in the sequel some ideas or facts around those kinds of topics, possibly not always directly related, are quickly evoked. The exposure will mainly be from an engineering perspective. Moreover, historical facts will frequently be taken from the technical history of Spain. ${ }^{3}$ As a starting point, it should be recalled

2. For the consideration of innovation vs invention (somehow Joseph A. Schumpeter vs Abbot P. Usher), the works of Vernon W. Ruttan (1959) and Govindan Parayil (1991), may be of help. See also, Arthur P. Molella (2005). 3. Técnica e Ingenieria en España (M. Silva, ed.) is a collection of eight books (in Spanish, composed of seven volumes, about 6.000 pages) edited by the Real Academia de Ingeniería, the Institución "Fernando el Católico", and Prensas de la Universidad de Zaragoza: http://www.raing.es/es/publicaciones/libros/ colecci-n-t-cnica-e-ingenier-en-espa. the fact that technology is not only "culture but a powerful cultural engine." This concept - as it is well known - did not shine in Ancient Greece.

Two ideas expressed by well-known philosophers as Juan de Dios García Bacca (1968), "the technician/technologist is a practising ontologist," and José Ortega y Gasset (1939), "the engineer is the technician/technologist par excellence," may open a question. Where has engineering been placed in the classification of knowledge in history? Because engineering is a direct-driving force in the transformation of the artificial landscape in which humans live (e.g., not too many things are so artificial as "natural parks"...), in the Discours preliminaire of the Encyclopedie of Diderot and D'Alembert (in the «Avertissement») they do not close the alternative between mathematics and natural sciences (physics), versus social sciences (economical, in particular). ${ }^{4}$ For some people this may be astonishing, perhaps explained because of the times in which was published. Nevertheless, it always contains a point to consider, like when hesitations appear in the task of classifying architecture as a technical or fine art profession.

Engineering uses the sciences. With important contributions to aeronautics and astronautics, the first recipient of the National Medal of Science of USA (1963), ${ }^{5}$ Theodore von Kármán (h. 1957) gives a knowledgeable and synthetic distinction: "The scientist describes what is; the engineer creates what never was" (in Alan L. Mackay, 1994). More than two centuries before, with a fund undoubtedly arrogant and naïve at the same time, the explicit proclamation of the mission of the Spanish Royal Corps of Military Engineers in the Age of Enlightenment was: "to remedy with the art [i.e., the technique] the defects of nature" (Ordinances, 1739).

To design is a main (not unique) task for engineers. A car, an aeroplane or a computer are by no means theorems or corollaries of any science. Engineering projects require a variable blend of creativity, intuition, experience, and science. A supplementary distinction between scientists and engineers is due to

\footnotetext{
4. This represents an alternative/complementary perspective of the classical Two cultures (scientific and humanistic) by Charles P. Snow (1964). In this sense, one additional point of view to consider is that of Guy Ortolano (2016: 118): "C.P. Snow's identification of 'two cultures', as the literary critic F.R. Leavis pointed out in 1962, represents not an insight but a cliché, one that invites the repetition of further clichés about the origins of a divided culture, the need to bridge cultures, the emergence of a third culture, or the reality of one culture".

5. It is interesting to quote the citation: "The National Medal of Science is awarded by the President of the United States to Theodore von Kármán for his leadership in the science and engineering basic to aeronautics, for distinguished counsel to the Armed Services and for promoting international cooperation in science and engineering".
} 
Herber A. Simon, the unique Turing Award (1975) and Nobel Prize (in Economy, 1978). Simon focuses on the difference between analysis and synthesis:

Natural science is knowledge about natural objects and phenomena. [...] We speak of engineering as concerned with synthesis, while science is concerned with analysis [...] The engineer, and more generally the designer, is concerned with how things ought to be - how they ought to be in order to attain goals and to function. (H. Simon 1996: 4-5).

In addition, it should be noted the existence of distinctive know-how in many companies or institutions, what makes their comparative differences. Mostly based on experiences, this "private" knowledge are uncoded in any scientific framework. In this sense, it may be surprising the distance between the validation of a process or protocol in a laboratory versus its efficient launching in a production plant, between a product conceived or synthesised in the laboratory versus its industrial version in the market.

\section{TECHNOLOGICAL PROGRESS: INTUITION, AUDACITY AND SOMETIMES FANTASY}

Frontiers or constraints to technological progress are of different kinds. Nevertheless, insufficient knowledge is a fundamental constraint. In architecture and civil engineering, for example, but not only, it is well-known that designing and building without "knowing enough" has been a constant throughout the history. "Construction has never waited until the theoretical problems posed by the builders themselves were solved," as Javier Manterola (2011: 419) says. To cross those borders and to jump over the obstacles with insufficiencies in understanding is a recurrent issue in the history of engineering.

Failures and successes are the two main sides of innovations. They involve risks, but if designs (or constructions) are not good enough (or clearly wrong), the integrity of next-generation designs can be enhanced by critically thinking about the reasons for the failure. In Henry Petroski (1985) are analysed several important cases (as a sequel, Petrosky (2012) look at design from a broader perspective). The titles of some chapters provide clear ideas. Examples of this are: Falling down is part of growing up, or When cracks become breakthroughs. In this context, it is paradigmatic the consideration of suspension bridges, most frequently used for long spans. Many of these (at least three in the USA and seven in Europe) collapsed or suffered significant damage in the XIX century. Using the "deflection theory" to suspension bridge design, the engineer Leon Moisseiff (a consultant engineer in the design and construction of the successful Golden Gate Bridge at San Francisco Bay, previously known as "the bridge that couldn't be built", open in 1937) defined the superstructure of the Tacoma Narrows Bridge (open the 1st July of 1940). Lighter and narrower, the bridge was much cheaper and increased the characteristic line minimalist at the aesthetical level. Nevertheless, excessive flexibility makes it collapse on the 7th of November of the same year, with only some four months of service. The reasons are complex to explain; roughly speaking, undamped rhythmic forces produced by a nonstrong wind make the bridge to enter into "intense resonant oscillation." This provokes it to fail. Failures and successes (fortunately more frequent) are the two sides of the coin of progress in engineering.

The principal cause for this failure was that aerodynamic forces were insufficiently understood. At those times, there seemed to be almost no recognition that wind created vertical movement at all and that this can be combined with some torsion effects. This fact makes the bridge absorbing much more energy from the wind (a kind of positive feedback, once again). As the main lesson, from that catastrophe the effect of the wind is much more carefully considered at design; so engineers test these kinds of designs using 3-dimensional models in a wind tunnel, somehow like aeroplanes. In summary, since the Tacoma disaster, deflection theory must be completed with aerodynamic stability analysis. This clear innovation helps in the subsequent designs.

Changing from hyper-stable to dynamic systems, in the design of planes, during the "heroic period," even designers died testing their own engines. Perhaps the first having this "dramatic honour" is the Spanish builder and aviator Antonio Fernández Santillana, (see, for example, José Luis Lindo Martínez, 2010).

From a much broader perspective, partially based in obtaining more productive varieties of cereals, the Neolithic revolution developed before any scientific knowledge on genetics; during the Enlightenment, the steam machine did work properly before the thermodynamics was established as a conceptual framework; as a third and last example, with the beginning of the 20th-century (1903), planes flew before the fluid mechanics discipline discover and integrate the fundamentals of boundary-layer theory (the first work on that topic is due to the German engineer Ludwig Prandtl, 1904), the conceptual framework that explain why machines "heavier than air" can fly. Even if embedded in an uncountable number of failures, using different try and error strategies, these are among the many-many successful technical histories. This is a proof of the technical boldness and persistence of humans.

The steam machine and the planes were driving forces for the development of new scientific disciplines, driving-forces to go behind some frontiers of the knowledge at the corresponding times. This last situation makes that sometimes - 
ignoring history, perhaps with preconceived ideological attitudes - people characterise engineering in a very restrictive or biased way as "applied science." Of course, many technical sectors did develop thanks to knowledge created in various scientific disciplines (as for example, organic chemistry or nuclear physic). In any case, based on "natural philosophy" or with the purpose to understand and improve human artefacts, frontiers of knowledge leading to revolutions have been pushed in historical terms: The Sciences of the Artificial (Herbert A. Simon, 1996).

Once again, technological innovation is not a fail-safe task. For example, many of the engineers at the Renaissance did enjoy "the illusion of unlimited efficiency" (Bertrand Gille, 1964: 8). As Lynn White $\operatorname{Jr}$ (1972: 41) points out, at the 15th-century and all over Europe, monarchs were "eager to increase not only their armed might but also the prosperity of their realms", and therefore they hire engineers that construct wonderful machines, palaces, and fortress, "helping to bankrupt every government which hired them". But this boldness is in some sense an historical invariant and, for example, during the Enlightenment, the French military engineer and architect Charles Lemaur at the service of the Spanish Crown convince the Count of Floridablanca and Francisco Cabarrús (financier) with the crazy aspiration of connecting Madrid with Seville through channels and rivers. Not only the fantastic problems with orography were underestimated, but the pluviometry of the corresponding regions was also openly neglected. "Fortunately" the disaster of El Gasco reservoir (the Guadarrama River) leads to the project to be forgotten. Therefore, even with the required financial resources, the "fantasy" leads sometimes to big failures.

\section{CULTURAL INSUFFICIENCY AND CULTURAL INERTIA}

In other cases, the frontiers are due to an insufficiently developed or in some sense biased "technical system." Bertrand Gille (1978) introduced this concept: "within some limits, as a very general rule, all techniques are, to various degrees, depending on one another, so that there should be some coherence between them." Examples of shortage in the technical system in XIX century Spain are the metallic Buda lighthouse (in the Ebro delta, Tarragona, designed by the civil engineer Lucio del Valle and opened in 1864), and the Destructor (the first "destroyer," specified by the naval officer Fernando Villamil, 1885). Both were excellent designs. Impossible to be constructed in the Spanish technical system of the moment; they were built in Clyde and Birmingham (U.K.), respectively. Analogous things can be said, for example, for the revolutionary Talgo II train (designed by the military engineer Alejandro Goicoechea, 1950) that was constructed with aluminium (to be lighter) by the American Car Foundry (Wilmington, Delaware, USA).

In some sense, this idea of the technical system is "drawing" frontiers depending on auxiliary or complementary technologies, availability and cost of raw materials and intermediate goods, trained human capital, market demand, economic factors (labour costs, interest rates, government policy, taxes, and management), etc. These shape the different circumstances in which the task can be developed, being appropriate to remember the classic "I am myself and my circumstances" of Ortega y Gasset (Meditaciones del Quijote, 1914). For example, the circumstances have always been an important driving force for the migration of talent. Due to "his circumstances," Juan de la Cierva was impelled to progress in the development of his autogiro in the UK (Cierva Autogiro Company) or USA (Pitcairn-Cierva Autogiro Company), for example; or Nikola Tesla to emigrate and work in the USA.

Among other frontiers of cultural nature, but very different among them, are the limits to the established knowledge (scientific and technical) and the aesthetical criteria. As science is part of the culture, the first case represents a manifestation of technical "cultural insufficiency," while in the second one is of "cultural inertia." New scientific knowledge may lead to the so-called by Ortega y Gasset "unpredictable technique" (in the Second Industrial Revolution exemplified by chemistry and electricity). From the middle of the 19-century, but definitely with the birth of the past one, this leads to progressively important investments in research laboratories and to promote new ways of training professionals. To increase the sense of reality of the new engineers, the new curricula will sometimes strength their relationships with laboratories (see, for example, A. Roca Rosell, 1996).

The idea of cultural inertia can be easily presented considering aesthetic. In the building sector, new materials lead to new forms, volumes, and surfaces. This happens, for example, when iron became a tested material in the construction field in the XIX century. The technical properties of stones and iron (later perfected by steel) based elements are quite different. In this case, classical established aesthetic criteria - basically rooted on the structural forms derived from well-known materials as stones and bricks - play the role of obstacles defining some cultural frontiers. As a transient solution, in the XIX century many new buildings, train stations, etc., were frequently "hid" by architects with classical materials like bricks. With time, new eyes were capable of distinguishing, appreciating and comparing the new structures with their spatial manifestations. 
This ended up decanting new aesthetic criteria, which hopefully were added to the pre-existing ones.

\section{ABOUT THE ORBUCULUM AND PREDICTIONS}

To predict new revolutions or changes of (scientific, technical, aesthetical, etc.) paradigms is a very difficult/risky task. ${ }^{6}$ Nevertheless, the literature is very rich in the casuistry of appreciations about the potential development of the know-how, what includes the theoretical knowledge. As some intentionally simple brushstrokes in the framework outlined by early aeronautics: (1) Esteban Terradas, in many respects one of the most important engineers of Spain in the 20th-century, around 1908-1909 though that aviation will be always a case of "small planes", not very interesting to transport heavy products and to deal in daily practice with very long distances, for example; (2) this appreciation was corrected by another engineer, Gaspar Brunet, the designer of a plane in 1909-1910, and author of the first and quite significant monograph on the topic in Spain (Curso de Aviación, 1910). Brunet did predict the existence of large "transatlantic planes" (as ocean liners exist); nevertheless, he fully underestimates the interest of helicopters. Nevertheless, some ten years later (in 1920) Juan de la Cierva start to develop the autogiro, and the world's first mass-produced helicopter (designed by Igor Sikorsky in the USA) appears in 1944. Just to put this in a broader context, let us mention that in 1895 (eight years before of the first fly of the Wright brothers) Lord Kelvin, the President of the Royal Society, claims "I have not the smallest molecule of faith in aerial navigation other than ballooning" (in other words: heavier-than-air flying machines are impossible or impractical). Clearly, aviation, like electricity before, or like nuclear energy later, belong to what were in their respective times "unpredictable" techniques.

Long-term technological predictions usually fail. This is somehow understandable, as the speed at which the technological progress is in constant acceleration. For example, simplifying, at the very end of the 1970s, standard computers may have central memories on the order of $100 \mathrm{kB}$; now, some 40 years later, the corresponding figure is of the order of one Terabyte ( $\mathrm{TB}=1.000^{4}$ bytes). In

6. For a discussion of the evolution of sciences (applicable to other fields, as technology) and the role of the (somehow diffused) concept of "paradigm", see the work of Thomas Kuhn (1970). The notion may have several sides as he pointed, for example, with: "A paradigm is what the members of a scientific community share, and, conversely, a scientific community consists of men who share a paradigm". other words, a factor of gain of ten million! This means a yearly-based rate of increase of the order of $50 \%$ ! As a related complementary figure, every decade supercomputers multiply their processing speed by one thousand: 1 Gigaflop in 1988 versus 1 Exaflop in 2018. ${ }^{7}$ Thus, for those 30 years, the computation power in flops increase in the order of $10^{9}$; otherwise stated, it has been doubled every year!

Through analytical calculations and simulations, this computational power leads to dramatic improvements in the design of new computers (positive feedback: the increase in computational power helps to improve the next generation of computer systems), but also to design:

- new materials (e.g., catalysers);

- new optimisation methods in energy production, storage, transport or consumption;

- new Decision Support Systems (DSS) able to take decisions over immense mass of data (transforming part of it in information, sometimes later in knowledge...);

- new concepts and techniques for the redesign of aspects of life (for example, to cure certain hereditary diseases);

- ...

As pointed out before, the "technical system" is a dynamic one that may have a positive feedback. This means the possibility of exponential growth, but this rate should not be alive forever. Saturations will appear if the technological paradigm is not changed. It can be said that, in some sense, we can approach some "predictions" in the actual paradigms, but what about if some new drastic changes on the know-how are mastered (e.g., in quantum computing, DNA computing...)? To predict any radical change is quite uncertain, but sooner or later radical changes will arrive. In any case, the idea of permanent exponential grows seems unreasonable.

In these circumstances, perhaps it is right to say that: "the best way to predict the future is to invent it" (Alan Kay, 1971). As a kind of corollary, thinking and working to shape the future condition our present. Thus, if basic pillars of technology are the materials, energy, information, and organisation, to which - at least for the moment- life may be added, how these lines will evolve? In short or middle terms, among many-many themes, it is necessary to advance frontiers with new materials (for example, for big and fast energy storage and saving systems), in nanotechnologies (with applications from medicine to almost any kind of material), for the production of energy (nuclear fusion?...), to deal with big data (not so difficult, and progressive) or for new means of calculation (as the mentioned quantum comput-

7. "Flops" or "flop/s" means floating point operations per second. Giga $=1.000^{3}$, while Exa $=1.000^{6}$. 
ing...), with new biotechnologies... Historically, the dedications of engineers and technologist have focused on the design and operation of "the artefacts"; on the horizon, the plant and animal kingdoms are being considered new artefacts. Very promising and risky we, the humans, are also included...!

\section{TECHNOLOGICAL PROGRESS: A SOCIAL PERSPECTIVE}

One of the perspectives to consider the development of the Industrial Revolution is to notice that for more than one century it strongly pushes "mechanisation", what can be considered as important "muscle and tool extension" of human capabilities. This integrates some (relatively) "simple" automatic control mechanisms based on feedback, as speed regulators for steam machines (Otto Mayr, 1970: 90-118.), later servomechanisms (c. 1873, to steer great ships; see, Stuart Bennet, 1979: 100-105). With the power of electronics it is possible to deal with huge masses of information. As a result, automation and robotics generalise the previous automatic control attempts, and it becomes appropriate to speak of "brain extension" (D.E. Noble, 1976).

Automation and robotisation allow: (1) to increase productivity; (2) to improve the quality and uniformity of products; (3) to save materials and energy. All these three facts lead to cheaper and better products. From another perspective, this leads for workers to: (1) greater security, and (2) more comfort while developing their tasks. Moreover, automation allows controlling systems that humans cannot (mainly due to the required speed of reaction, or the continued maintenance of demanding attention), "making possible the incredible," as in the control of certain planes or energy production systems like nuclear power stations. Anyway, these advantages should be considered in a broader framework, because investments in this field are frequently at the point of confronting the possible survival for the production system (or its full relocalisation abroad) versus reduction in the number of employees. Nevertheless, these questions rise other very relevant issues as the number of hours per week that employees should work, or the need of charging those systems with taxes for the functioning of robots (able to work three shifts a day, seven days a week, without retirement), for example. With "robot" as keyword, scanning the titles of papers in the IEEE Technology and Society Magazine, we found contributions as:

- "Ethical robots in warfare" (2009);

- "Robotics, the New Industrial Revolution" (2012);

- "Robot Enhanced Therapy for Children with Autism Disorders: Measuring Ethical Acceptability" (2016);
- "Sex Robot Matters: Slavery, the Prostituted, and the Rights of Machines" (2016); or

- "Socio-Economic and Legal Impact of Autonomous Robotics and AI Entities: The RAiLE Project" (2018).

Using, for example, "privacy" instead of "robot", among many entries we can find:

- "Face recognition technology: security versus privacy" (2004);

- "Keyloggers: Increasing threats to computer security and privacy" (2009);

- "Privacy in the Age of Google and Facebook" (2011);

- "Privacy Issues and Solutions in Social Network Sites" (2012); or

- "Privacy vs Security in National Emergencies" (2012).

A central underlying question is: a significant part of the advantages of new technologies should be primarily for a small proportion of the society or not? Having transnational companies with a power superior to medium-sized states, whose managers have not been elected democratically, it is reasonable? Moreover, to increase social inequality does not contribute to social stability. In any case, I do not support the position of those (populist) persons that - from a self-granted moral authority simply feel people as subjects of social rights, almost completely forgetting obligations.

Thinking new ways for social organisations is clearly a matter to consider. Humanities should make efforts in these lines rising proposals for discussion.

\section{LAST BUT NOT LEAST: GAIA OR THANATIA?}

Among the important frontiers are the limitations on basic physical ingredients in our "blue planet." The fact is that the extraction of fossil fuels and mineral resources has grown exponentially since the early 20th century and far from decelerating, it is expected to increase in the coming decades. The Limits to Growth (Meadows et al., 1972) already alerted that if demand of metals and fossil fuels maintained the same trend, mankind would sooner or later be close to collapse. (Valero and Valero, 2015: vii).

In this last monograph, economic and thermodynamic (heat dissipation and materials deterioration and dispersion; in fact, quality degradation) arguments are inter-leaved, giving a refreshing perspective in which - like in The Limits to Growth - the quantifications should be considered as mere approximations, expression of possible tendencies. In any case, drawing some scenarios, "food for thinking" about the Earth's progressive 
deterioration is provided. Therefore, a main question may be raised: Is Gaia becoming Thanatia (in ancient Greece, Thanatos was the personification of death), a resource exhausted planet? As a complementarily and crucial in practice question: how to have a sustainable planet?

The problems are multiple, starting with the progressive exhaustion of very diverse natural resources. This does not only concern oil, but many other materials such as rare-earth elements (metals), so crucial in the production of devices as computers or mobile phones. These depletions run parallel to an exponential increase in garbage, part of which is irretrievably going to the sea (e.g., phosphates, or entirely different plastic elements that are passing to the food chain), even to the atmosphere $\left(\mathrm{CO}_{2}, \mathrm{NO}_{\mathrm{X}}, \mathrm{SO}_{2}\right.$, etc. $)$, in addition to the many-many territorial warehouses in so diverse places. In other words, depletion and degradation of the natural environment run in parallel. The exponential consumption of various substances will lead to political and military crises, as the shortage of water provoked military conflicts from a long time ago. In other words, there are many Achilles' heels to unlimited growth, not just oil.

On the other hand, reusing/collecting is not the same as recycling. In this last case, we always move on cyclical processes with decreasing yields and economic and physical side-conditions; in particular, the consumption of other materials on the recycling processes, bring in turn to enter into additional processes of diminishing returns, and so on...

All these reflections are going beyond technology, a dimension in which the technological progress has advanced the evolvement of society from other points of view and disciplines, the humanities for example.

\section{BIBLIOGRAPHICAL REFERENCES}

Bennett, Stuart (1979). A history of Control Engineering, 1800-1930. London: The Institution of Electrical Engineers/Peter Peregrinus.

García Bacca, Juan de Dios (1968). Elogio de la Técnica. Caracas: Monte Ávila (Colección Estudios).

García Tapia, Nicolás (1992). "Some designs of Jerónimo de Ayanz. Related to Mining, Metallurgy and Steam Pumps", History of Technology, 14, pp. 135-150.

Gille, Bertrand (1964). Les Ingénieurs de la Renaissance. Paris: Hermann.

----- (dir.) (1978). Histoire des techniques: technique et civilisations: technique et sciences. Paris: Gallimard.

Kuhn, Thomas S. (1970). The Structure of Scientific Revolutions (Enlarged, 2nd ed.). Chicago: University of Chicago Press.

Lindo Martínez, José L. (2010). Antonio Fernández Santillana, el primer aviador de España: en recuerdo del I centenario de su muerte. Madrid: Ministerio de Defensa.
Mackay, Alan L. (1994). Dictionary of Scientific Quotations. Bristol Institute of Physics.

Manterola Armisén, Javier (2011). "La construcción y los materiales metálicos”, in M. Silva Suárez (ed.), Técnica e ingeniería en España, vol. vi: El Ochocien-tos. De los lenguajes al patrimonio. Zaragoza: Real Academia de Ingeniería/Institución «Fernando el Católico»/Prensas Universitarias de Zaragoza, pp. 415-450.

Mayr, Otto (1970). The Origins of Feedback Control. Cambridge, Massachusetts: The MIT Press.

Meadows, Donella, Dennis Meadows, Jørg Randers, and Williams W. Behrens (1972). The Limits to Growth. New York: Universe Books.

Molella, Arthur P. (2005). "The Longue Durée of Abbott Payson Usher, A History of Mechanical Inventions", Technology and Culture, 46 (4): 779-796.

Noble, Daniel E. (1976). The U.S. Transition from Muscle Extension to Brain Expansion, Proceedings of the IEEE, Vol. 64(9): 1418-1423.

Ortega y Gasset, José (1939). Meditación de la Técnica y otros ensayos sobre Ciencia y Filosofia. Madrid, Revista de Occidente. (It is translated into English, Thoughts on Technology; French: Méditation sur la Technique; Portuguese: Meditação sobre a Técnica; etc.).

Ortolano, Guy (2016). "Breaking Ranks: C.P. Snow and the Crisis of Mid-Century Liberalism, 1930-1980", Interdisciplinary Science Reviews 41 (2-3): 118-132.

Pacey, Arnold (1974). The maze of ingenuity. Ideas and idealism in the development of technology. London: Allen Lane.

Parayil, Govindan (1991). "Schumpeter on Invention, Innovation and Technological Change". Journal of the History of Economic Thought, 13 (1): 78-89.

Petroski, Henry (1985). To Engineer is Human: The role of failure in successful design. New York: Barnes \& Noble.

---- (2012). To Forgive Design. Understanding Failure. Cambridge, MA: The Belknap Press of Harvard University Press.

Roca Rosell, Antoni M. (1996). "L'enginyeria de laboratori, un repte del noucent", Quaderns d'Història de l'Enginyeria, I, pp. 197-240.

Ruttan, Vernon W. (1959). "Usher and Schumpeter on Invention, Innovation and Technological Change", The Quarterly Journal of Economics, 73 (4): 596-606.

Silva Suárez, Manuel (2004-2013). Técnica e Ingeniería en España (8 vols.). Zaragoza: Real Academia de Ingeniería, Institución "Fernando el Católico" y Prensas Universitarias de Zaragoza.

Simon, Herbert A. (1996, 3rd ed.). The Sciences of the Artificial, Cambridge, Massachusetts: MIT Press.

Snow, Charles Percy (1998). The two cultures. Cambridge: Cambridge University Press. (First part, 1959; second part 1964).

Valero Capilla, Antonio, and Alicia Valero Delgado (2015). Thanatia: the destiny of the Earth's mineral resources: a thermodynamic cradle-to-cradle assessment. London: World Scientific Publishing Co. Pte. Ltd.

Weizsäcker, Ernst von, and Anders Wijkman (eds.) (2018). Come On! The Report of the Club of Rome, at its 50th Anniversary. New York: Springer-Verlag.

White (Jr), Lynn (1972). The flavor of Early Renaissance Technology, in Developments in the Early Renaissance (B.A. Levy, ed.), Albany: State University of New York Press, pp. 36-57. 
$\because$ Taylor \& Francis

Taylor \& Francis Group

http://taylorandfrancis.com 


\title{
A silent revolution
}

\author{
João Seixas \\ Departamento de Física, Instituto Superior Técnico, Universidade de Lisboa, Portugal \\ Laboratório de Instrumentação e Física Experimental de Partículas, LIP-Lisboa, Portugal
}

\begin{abstract}
Variational principles are a cornerstone of Modern Physics. In this contribution, I analyse the impact that these techniques had (and still have) in shaping the contemporary scientific thought and how they influenced the way scientists look at Nature.
\end{abstract}

Keywords: Variational principles, classical mechanics, relativity, quantum physics, quantum information

\section{A NEW INTERPRETATION OF NATURE}

Science - as all forms of human knowledge - aims at discovering the major principles that govern all observable phenomena and, in the process, clarify the role of humankind in the order of all things. This ideal, which most people, literate or not, vouch for, hides a much more troubling question: what will happen when humankind unravels all secrets of Nature if this is ever possible? In this limit, does a Human become God? Alternatively, is the nature of God beyond all possible knowledge?

The answer to this question certainly creates a major divide among humans of all credos. For instance, Samkhya, one of the six Darshanas of Hindu philosophy, clearly states that the proof of the existence of God cannot be obtained from evidence since Purusha, the uncaused Cause is eternally free, never bound, never released (SINHA2003). Therefore, Purusha is beyond all knowledge and can be known neither by unravelling the inner mechanisms of thought nor by physical experimental means.

The reader might wonder by now why a seemingly serious scientist should incur in such unusual pathways. The reason is that most physicists since the XVII century took the habit of acting like God (if it exists...), deciding what Nature should do from an exploration of other possible (or impossible) trajectories for its evolution.

The idea can be traced back to Euclid's Catoptrics (c. $320 \mathrm{BCE}$ ), but it was Heron of Alexandria (c. 60) who first stated it in a very simplified form. What Heron discovered was that when describing the (possibly) multiple reflections of light between two points Nature always follows the path having the least possible length. In other words, if one explores other possible nearby paths between the two points subject to the conditions of the actual process (namely in what concerns the number of reflections that light must undergo), then the path that Nature follows is the shortest in length.

Heron's observation condensed in the modern form of a Principle of Least Action by the hand of Pierre de Fermat in his text "Analyse des réfractions" (1662) who enunciated it as a principle of least time. In brief, Fermat states that "Nature operates by the simplest and most expeditious ways and means" and from this standpoint, he was able to explain the law of reflection of light and the Snell-Descartes law of refraction.

Around 1744, Pierre Louis Maupertuis and Leonhard Euler independently reached the conclusion that this approach could be extended to other fields of Physics and, in particular to Mechanics. By this time several mathematicians and physicists - which included the twin brothers Bernoulli and the Marquis de l'Hospital-were developing the idea of using this same approach to the mathematical problem of finding the extrema of functions and to explore new ways of treating problems in Mechanics.

The decisive step towards a full-fledged methodology for the treatment of problems in Physics came from one of the most profound physicists and mathematician of the XVIII century: JeanBaptiste le Rond d'Alembert. In his Traité de Dynamique (1743) he proposed to consider new displacements of a physical system, unused by Nature, to create new trajectories that it could have followed (see Fig. 1). Because they do not really exist these displacements are called "virtual". To decide which ones effectively take place d'Alembert used the concept of Work. In Physics Work is defined as the projection of a force along a given direction of motion and thus measures how 


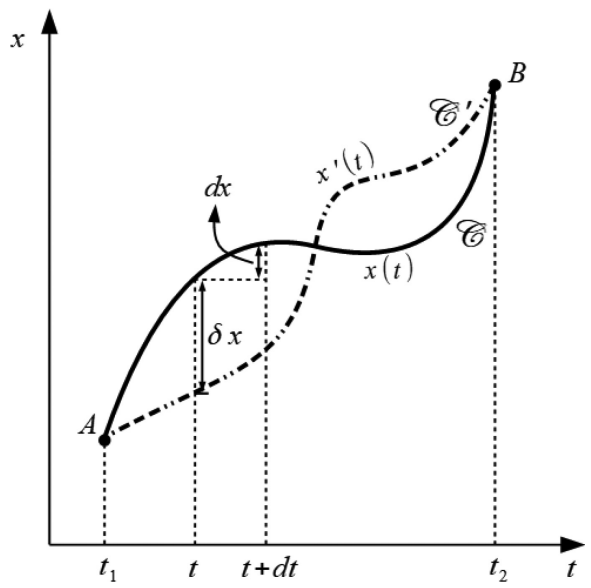

Figure 1. The method of d'Alembert creates new possible time parametrised paths for the system compatible with constraints. The quantity $\delta \mathrm{x}$ is the virtual displacement while the quantity $\mathrm{dx}$ is what is called the differential.

effective a force is to produce a displacement in this direction. For instance, if the force is perpendicular to the proposed direction its projection is zero and has, therefore, no effect. As should be expected, the work of a real force along the direction of a virtual displacement is called a Virtual Work.

What d'Alembert was able to prove was that keeping the forces acting on the system in place, only the virtual displacements which produce no Virtual Work were chosen by Nature (Principle of Virtual Work). To make things clearer, one can play God and explore other possible behaviours of the system, but in the end, only the one that produces no (virtual) work is effectively realised in practice.

The Principle of Virtual Work has far-reaching consequences, namely in what concerns one of the most mysterious concepts of Nature: Inertia. To understand why we must use the methodology of conceptual experimentation. Let us assume that a given observer standing on a platform is following the free fall of an object. The force of gravity, because of Newton's 2nd Law of Mechanics, forces the object to have an accelerated motion. When the object passes by the observer, a mechanism releases the platform, and the observer finds himself in free fall. Newton's 1st Law (Principle of Inertia) then tells us that the observer, due to the accelerated motion, feels an inertial force equal but opposite in direction to the force of gravity. This applies to all things that move in his frame of reference and therefore the falling object, from the observer's new point of view, is also subject to this force. Consequently, from the new point of view of the observer, the object behaves as if NO forces were present!
This is where the Principle of Virtual Work sneaks in. Since now there are no forces, the dynamical problem became a problem in Statics for which the Principle of Virtual Work was designed. We can thus state that among all the movements that the system could have followed, only the ones in which the applied forces plus the inertial forces perform no Virtual Work are chosen by Nature. Therefore, we can play God, but only according to d'Alembert's rules.

Several important problems, which include the brachistochrone problem of determining a path corresponding to least time, were solved (in particular, by Newton) using the method of d'Alembert.

This approach was further developed by the Italo-French mathematician Joseph-Louis Lagrange and during the 19th century by the English mathematician Sir William Rowan Hamilton. They created what is now called the Calculus of Variations (LANCZOS1970).

There is, nonetheless, a question, which was implicit in our idealised example above: the identity between gravity and inertial force is only possible because the mass present in the gravitational force is equal to the mass present in the inertial forces. This question, which occupied several distinguished physicists in XVIII and XIX centuries and, most importantly, Heinrich Hertz, could only be solved in the context of Einstein's General Relativity Theory, also called Geometrodynamics. The solution, for which Hertz already had an intuition, was Geometry. This beautiful and amazing outcome, wrought together by Mathematics and Physics, was a direct consequence of M. d'Alembert trying to play God.

\section{WHO PLAYS WITH WHOM?}

Around 1930 the discoveries related to the structure of the atom created havoc in the well-established fields of (what is now called) Classical Physics. Mechanics, Electromagnetism, Thermodynamics, all seemed submerged in deeply troubled waters. It took the genius of Werner Heisenberg, Niels Bohr, Max Born, Erwin Schrödinger and Paul Dirac to build a new theory that could give a meaning to the strange new phenomena that had been discovered. This new theory is Quantum Mechanics.

The postulates of Quantum Mechanics as we know them today were, however, established by the Hungarian-American mathematician, physicist and computer scientist John von Neumann (Neumann János Lajos). The postulates are as strange as the phenomena themselves:

1. The state of a quantum system is represented by a mathematical entity called a "ket", which 
we write as, for instance, $\mid \Psi>$. This ket, which exists in the space of all states, contains all the information concerning the system.

The state of the system usually is a superposition of "basis kets" which serve as reference for the space of states. This space is equipped with the notion of overlap of states.

2. Every observable attribute of the system is represented by an operator, which acts on the kets that represent the state of the system. An operator (which is also called, for this reason, an observable) is like an apparatus that swallows a ket, digests it and gives back another ket corresponding to the same state or another state (see Fig. 2). For instance, measuring the position of a system in Quantum Mechanics amounts to applying the "position operator" to the ket representing the system to obtain as a result the value of the position.

It is of extreme importance to know that in some cases the order of measurement is crucial. For instance, measuring the position and then the velocity is not the same as measuring first the velocity and then the position. The outcome state of the complete measurement is not the same in the two cases. Therefore, in Quantum Mechanics measurements can be (and in general are) noncommutative. This is true, incidentally for all the important basic physical quantities such as position and velocity, as we saw above. Although we cannot prove it here, this property is at the heart of Heisenberg's Uncertainty Relations.

3 . The only possible result of the measurement of an observable $\mathrm{O}$, using the pictorial language in Fig. 2, corresponds to a value "o" associated to a state that remains unchanged under the action of the operator (this state is called an "eigenvector" or "eigenstate" of the operator).

This postulate is what is at the origin of the word "quantum" in Quantum Mechanics. If, as is true in the case of a hydrogen atom, that the

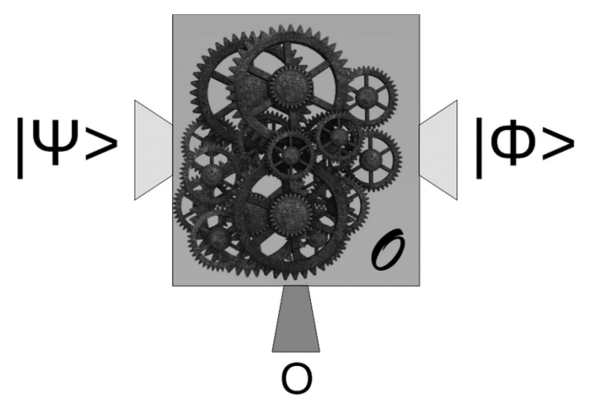

Figure 2. Cartoon description of the mechanism of an operator $\mathrm{O}$ acting on state $\mid \Psi>$. The operator provides as an output the state $\mid \Phi>$ while at the same time provides information "o" on the original state. possible outcomes are numerable (or, as it is also said, discrete), then the statement is shocking, to say the least. A measurement of the energy of the hydrogen atom will yield only one of a discrete set of values.

What is even more shocking is that this postulate reflects an overwhelming amount of experimental evidence such as the discrete spectral lines observed in the radiation from a tube of hot hydrogen gas.

4. When a measurement of an observable $O$ is made on a generic state $|\psi\rangle$, the probability of obtaining a given outcome is given by the square of the projection of the original state over the outcome eigenstate of the operator.

This is one of the most important postulates since it states that we can only obtain PROBABILITIES for a given outcome and not a result with full certainty. Therefore, Quantum Mechanics is a PROBABILISTIC theory, but a very special one, as we shall see below.

In Quantum Mechanics a projection of a state $\mid \psi>$ onto another state $\mid \Phi>$ is written as $\langle\psi \mid \Phi\rangle$. The state on the left is called, in Dirac's notation, a "bra", the right one, as we already know, a "ket". The projection is thus a "bracket", and the probability is the square of the bracket.

Of course, the sum of the probabilities for all outcomes must add up to $100 \%$ since one of them must occur.

So it seems, in the picturesque words of Einstein, that God plays dice with us. We can play dice with Him by making an experiment, but we have to get used to the fact that He decides who wins.

5. Immediately after the measurement, the state of the system collapses to the particular state associated with the measured outcome.

For the "habitués" of Quantum Mechanics, this postulate goes under the nickname of "wavefunction collapse", meaning that after the measurement the state of the system is INSTANTANEOUSLY changed to the one appropriate for the measured value. Nobody (and this really means nobody!) feels comfortable with this postulate (see for instance (BOHM1993) or (BELL1966)), but it is backed up by massive amounts of experimental evidence.

It is important to clarify that if one performs a measurement obtaining a given result and changing the state of the system to an eigenstate of the operator representing the observable under consideration, a subsequent measurement of the SAME observable is not subject to a probabilistic outcome. After the wavefunction collapse, ALL measurements of the same quantity yield the SAME value with probability $100 \%$. Once God won the game He is a bit unfair because He keeps winning by using the same formula. 
6. The time evolution of the state is given by an evolution operator.

This postulate is not important in the context of this communication, but it contains a crucial piece of information. Quantum Mechanics is indeed a probabilistic theory, but the evolution of the probabilities is deterministic and given by this evolution operator.

Before we end this section, it is mandatory to establish a bridge with d'Alembert's method. Can we play God as we were taught by d'Alembert also in Quantum Mechanics, and try other routes for the evolution of a system other than the actual one that it decides to follow? The answer, given by Richard Feynman, is YES. However, we must realise that the different paths that a system can follow are now not mutually exclusive: EVERY path is possible; ALL paths can take place simultaneously, each with a given probability. The one chosen by Nature is the one with the highest probability. We can still play God, but unfortunately, the number of hands we have to deal with is infinite. Consequently, we can only win the game in a very limited number of cases. Playing God is indeed dangerous when you are not the real One...

\section{A QUANTUM COMPUTER}

Now, you may ask, what has Quantum Mechanics to do with computers? The point is that a computation is actually an operation over a given input, which produces a given output. In our classical computers, this means providing a sequence of digits 0 and 1 to a machine (operator) that yields another sequence of 0 and 1 as output. Here is the catch: classically the basic unit of computation is a binary digit, or bit, which can only take the values 0 or 1 . However, if we shift to the quantum paradigm the basic unit is a state which can also be $\mid 0>$ AND $\mid 1>$. A state of this type which is a combination of state $\mid 0>$ and state $\mid 1>$ is called a qbit.

Qbits constitute the basis of a silent revolution that is taking place as we speak. They are states that are acted upon by quantum operators engineered to perform the right evolution from the initial state to the required final one. We are entering the age of quantum technologies.

Contrarily to what one might think this revolution is mandatory. As computer processors evolve, less and less electrons are used to perform the computation. We are entering a phase in which only very few electrons are being used, which means that the quantum properties of electrons can no longer be neglected.
At the heart of quantum computation is a property of Quantum Mechanics that we had not the opportunity to discuss until now. Quantum Mechanics allows for NEGATIVE probabilities and INTERFERENCE between the states. These two properties allow for an incredible speedup in certain types of computation, especially the hard ones (AARONSON2013) (NIELSEN2010).

At the same time, Heisenberg's Uncertainty Relations (or the postulates of the previous section) tell us that if you measure a given state, in general, you destroy that state and construct another one. So suppose you build a communication channel and want it to be safe. Quantum Mechanics give you the ultimate security: if anyone tries to eavesdrop your channel, he or she will have to make a measurement on it, thereby irrevocably destroying the channel (not getting any information) and making his/her presence wide open.

The technologies to put all these developments in place are either already known or in the process of being developed. Therefore, information processing, communications, and information safety (cryptography) will undergo a fundamental revolution in only a few years from now. The consequences for society are immense.

What will happen when this new paradigm < will be in place? Nobody knows. However, it is clear that there is no escape from continuing to play God, despite the fact that our Opponent certainly wins most of the time.

\section{BIBLIOGRAPHICAL REFERENCES}

Aaronson, S. (2013) Quantum Computing since Democritus. Cambridge: Cambridge University Press.

Bell, J.S. (1966) "On the problem of hidden variables in quantum mechanics”, Rev. Mod. Phys. 38 (1966) 447.

Bell, J.S. Bell (1987), Speakable and Unspeakable in Quantum Mechanics. Cambridge: Cambridge University Press.

Bohm, D. and Hiley B.J. (1993) The Undivided Universe. London: Routledge.

Bohm, D. (1957) Causality and Chance in Modern Physics. London: Routledge \& Kegan Paul and D. Van Nostrand.

Lanczos C. (1970) The Variational Principles of Mechanics. Toronto: University of Toronto Press.

Nielsen M., Chuang I. (2010) Quantum Computation and Quantum Information. Cambridge: Cambridge University Press.

Sinha N. (2003) The Samkhya Philosophy. New Delhi: Munshiram Manoharlal Publishers. 


\title{
A paradigm for the $21^{\text {st }}$ century considering fuzzy logic
}

\author{
Gilson Braviano \\ Departamento de Expressão Gráfica, Universidade Federal de Santa Catarina, Brazil
}

\begin{abstract}
This paper presents some considerations about how uncertainty has been treated in the last 25 centuries, pointing out the vision of some philosophers of the ancient, middle, modern, and contemporary periods.

Fuzzy logic is presented as a possibility for approaching the uncertainties that characterise the world around us.

Based on the treatment of uncertainty, the transdisciplinary view of Complex Thought, and some postmodern philosophical currents, the paper generates reflections to the establishment of a scientific paradigm adapted to the beginning of the 21 st century.

Four adaptations are proposed in the current paradigm: the realism becomes relative realism, the materialism is considered regarding representativeness and methodology, the dichotomization of the reality migrates to a monistic model, and the determinism is seen in a probabilistic way.
\end{abstract}

Keywords: Uncertainty, fuzzy sets, fuzzy logic, postmodern paradigm

\section{THE TREATMENT OF UNCERTAINTY IN SCIENCE}

The Greek philosopher Aristotle (384-322 BC) is considered the founder of logic because he was the first thinker to make a systematic study of the types of arguments. He has worked extensively with categorical propositions, which establish a relation between classes, as every human being is mortal, for example, which considers the class of humans included in the class of mortals.

However, there are other possibilities for relating these same classes: some human beings are mortal, some human beings are not mortal, and no human being is mortal. In this way, Aristotle postulated that a class might be entirely or partially included in another class.

These relations would be governed by three fundamental principles:

- The principle of identity (A is A), indicating, for example, that a ball is a ball;

- The principle of non-contradiction (A and non-A cannot both be true, represented by $\mathrm{A} \cap \overline{\mathrm{A}}=\phi$ in a set language), that is: a given object is a ball or it is not a ball; and

- The principle of the excluded middle (there exists no third term $\mathrm{T}$ that is simultaneously $\mathrm{A}$ and non-A, represented by $\mathrm{AUA} \overline{\mathrm{A}}=\mathrm{X}$ in a set language).

These principles have been questioned and debated by philosophers and researchers since Ancient Greece. Barros and Bassanezi (2010) point out the condition of subjectivity, as inherent in language, unlike the uncertainty that arises from the randomness of events - which is well developed and today occupies a prominent place in the gallery of Mathematics. Thus, certain expressions commons in our daily lives - which are transmitted and correctly understood linguistically between interlocutors - are not adapted to the traditional mathematical treatment.

A central idea in the philosophy of Plato (c. 428-348 BC) is that "in the real word, elements are perturbed by imperfection, and thus, for example, there exists no element that is perfectly round" (Kandel, 1986: 1).

Some reflections on these principles in common situations are presented below. Imagine that you are collecting the weight of some $1 €$ coins to use this information to determine if there is a significant difference in weight between true and false coins. If your balance only shows the measure with one decimal place, a coin that weight in the balance is $7.5 \mathrm{~g}$ may have the actual weight between $7.45 \mathrm{~g}$ and $7.55 \mathrm{~g}$. The confidence associated with this measure is limited by the imprecision of the equipment used and can be affected by a calibration error.

This situation is closely related to the principle of uncertainty, created in 1927 by Heisenberg (1901-1976), which indicates that it is not possible to know precisely and at the same time the position and velocity of a subatomic particle. Then, the truth-values of certain propositions are inherently indeterminate due to fundamental limitations of measurement. 
Now the second reflection deals with how each person perceives a particular position about its limits. This position may refer to the stage in the performance of a task or the liquid present in a bottle containing half the volume of water. In this second case, is this bottle half-full or half empty? Similarly, how two people measuring $1.65 \mathrm{~m}$ and $1.98 \mathrm{~m}$ will describe someone who measures $1.80 \mathrm{~m}$ ? Would he be called tall or short?

Finally, observe the next situation, related to the propositional logic, containing the rule: if the employee takes approximately 3 hours to generate the $3 D$ model of a simple piece, his work rate is slow. How to deal, in logic away, the linguistic variables expressed by the terms about, simple and slow?

The described situations will not be easily modelled using classical logic, in which every proposition is either true or false. According to Klir and Yuan (1995: 217), "the basic assumption upon which classical logic (or two-valued logic) is based has been questioned since Aristotle".

This philosopher, in dealing with ambiguity and imprecision, considered that the causes of language's fallacies - erroneous logical reasoning leading to an erroneous conclusion - were related to its content and not to the way in which reasoning proceeded.

In the same vein, the absolute scepticism - the basis of the philosopher Pyrrhus (365-275 BC) -, considers that different and contradictory opinions manifested by people on the same subjects are one of the primary sources of errors, as well as the human senses, which would not be trustworthy. It is extremely common that while some employees working in the same environment consider the temperature pleasant while others report feeling thermal discomfort. Thus, the thermal sensation depends, in fact, on the individual-temperature relationship and not just on the temperature variable. Likewise, the time associated with a specific situation may not be as important as the perception people have of it: five minutes in a row to pay a bill seem like an eternity, but five minutes in an art show flies with incredible speed.

Like Pyrrhus, the Frenchman René Descartes (1596-1650) also blamed sensory perceptions for the frequent errors of human knowledge. In this sense, there are several examples of optical illusions that deceive the human vision, causing us to see things that are not present or inconsistent elements. These failures in visual, auditory, tactile, and olfactory perceptions depend on the experiences, knowledge, beliefs, theoretical assumptions, and expectations of the observer.

The philosophical view of Protagoras (c. 480$410 \mathrm{BC}$ ) generated a great subjectivism in considering that the world is what each individual or social group can perceive, being the reality relative to each one, dependent on its dispositions, conceptions, modes of being and living. For him, any thesis could be regarded as false and true at the same time, depending on the perspective of each one. Thus, a person measuring $1.80 \mathrm{~m}$ can be tall (in the perception of someone measuring $1.65 \mathrm{~m}$ ) and at the same time short (when seen by someone who measures $1.98 \mathrm{~m}$ ).

Then, one of the paradigms studied in the 20th century is the concept of uncertainty. Two classical measures of information regarding uncertainty were established by Hartley (1928), based in classical sets theory; and Shannon (1948), measuring the entropy related to any experience having a finite number of possible outcomes.

Besides, measures of dissonance and confusion were created in the 1980s given two generalisations of Shannon entropy, both based on the mathematical theory of evidence.

According to Cox (1999: 46), "we often use the same term to describe imprecision and uncertainty in only slightly related areas of measurement". Therefore, uncertainty - also understood as inexactness, ambiguity, non-specificity, vagueness and inconsistency - might be treated by extending the classical two-valued logic, assuming that a number can express truth and falsity in the unit interval [0,1]. This idea, introduced by Zadeh (1965), will be exposed in the next section.

\section{FUZZY SETS THEORY}

The crisp set A is defined in such a way as to dichotomise the individuals in some given universe $\mathrm{X}$ of discourse into two groups: members, those that belong in the set; and non-members, those do not.

However crisp sets are not adapted to represent categories where boundaries are vague, and the transition from member to non-member is better expressed by a gradual way rather than abrupt. Thus, fuzzy sets introduce vagueness by eliminating the sharp boundary.

A fuzzy set A can be defined mathematically by assigning to each possible individual $\mathrm{x}$ in the universe of discourse $X$ a value $\mu_{A}(x)$ in $[0,1]$ representing its grade of membership in the fuzzy set. Thus, if $\mu_{\mathrm{A}}(\mathrm{x})>\mu_{\mathrm{A}}(\mathrm{y})$ then $\mathrm{x}$ belongs more than $\mathrm{y}$ to fuzzy set A.

Because full membership and full nonmembership in the fuzzy set are indicated by the values of 1 and 0 , respectively, we can consider the crisp set to be a particular case of the more general fuzzy set for which only these two grades of membership are allowed.

In this sense, to define the fuzzy set A described by positive real numbers close to 2 we may consider that: 